\title{
Justyna Liguz
}

Muzeum Zamkowe w Malborku Oddział w Kwidzynie;

j.liguz@zamek.malbork.pl•https://orcid.org/0000-0002-6069-2876

\section{Inter Arma. Wizyta Stefana Żeromskiego, Jana Kasprowicza i Władysława Kozickiego na Powiślu w 1920 r.}

\author{
Inter Arma. A visit of Stefan Żeromski, Jan Kasprowicz and Władysław \\ Kozicki to Powiśle in 1920
}

\section{Inter Arma. Besuch von Stefan Żeromski, Jan Kasprowicz und Władysław Kozicki im unteren Weichselland (Powiśle) im Jahr 1920}

\author{
Słowa kluczowe: $\quad$ plebiscyt, Kwidzyn, Górki, Powiśle, Żeromski, Kasprowicz \\ Keywords: $\quad$ plebiscite, Kwidzyn, Górki, Powiśle, Żeromski, Kasprowicz \\ Schlüsselwörter: $\quad$ Plebiszit, Marienwerder, Górki, unteres Weichselland, Żeromski, Kasprowicz
}

\section{STRESZCZENIE}

Tekst omawia wizytę Stefana Żeromskiego, Jana Kasprowicza i Władysława Kozickiego na Powiślu w maju i czerwcu 1920 r. Ostatnie tygodnie kampanii plebiscytowej skłoniły podsekretarza stanu w Ministerstwie Spraw Zagranicznych Stefana Dąbrowskiego do podjęcia działań, które z jednej strony miały wesprzeć Polaków przed głosowaniem, z drugiej rozpowszechnić sprawę plebiscytu w Polsce. Artykuł zawiera próbę odtworzenia chronologii podróży literatów, podjętych działań oraz spotkań na terenie Zachodniopruskiego Okręgu Plebiscytowego z siedzibą w Kwidzynie. W dotychczasowej literaturze większość relacji oparta jest na opowiadaniu Stefana Żeromskiego Inter Arma, natomiast lektura wywiadów i publikacji w prasie po opuszczeniu Powiśla uzupełnia wydarzenia z czerwca 1920 r. o nowe fakty.

\section{ABSTRACT}

This text discusses the visit of Stefan Żeromski, Jan Kasprowicz and Władysław Kozicki to Powiśle in May and June 1920. The last weeks of the plebiscite campaign urged Stefan Dąbrowski the undersecretary of state in the Ministry of Foreign Affairs - to undertake actions that on the 
one hand would support Poles before the vote, and on the other hand publicize the plebiscite in Poland. The article attempts to reconstruct the chronology of the trip taken by the writers, as well as their actions and meetings in the territory of West Prussian Plebiscite Region with the main seat in Kwidzyn. Most research has been so far based on a narrative by Stefan Żeromski entitled Inter Arma. However, interviews and press publications issued after the writers left Powiśle broaden our knowledge of the 1920 events by new facts.

\section{ZUSAMMENFASSUNG}

Der Text bespricht den Besuch von Stefan Żeromski, Jan Kasprowicz und Władysław Kozicki im unteren Weichselland (Powiśle) im Mai und Juni 1920. Die letzten Wochen der Plebiszitkampagne veranlassten den Unterstaatssekretär im Außenministerium Stefan Dąbrowski zu Aktivitäten, die einerseits die Polen vor der Abstimmung unterstützen und andererseits das Thema Plebiszit in Polen verbreiten sollten. Der Artikel versucht, die Chronologie der Reisen, Aktionen und Treffen der Schriftsteller auf dem Territorium des westpreußischen Plebiszitbezirks mit Sitz in Marienwerder wiederzugeben. In der bisherigen Literatur stützen sich die meisten Darstellungen auf Stefan Żeromski Kurzgeschichte Inter Arma", während die Lektüre von Interviews und Veröffentlichungen in der Presse nach dem Verlassen der unteren Weichsellandes die Ereignisse des Juni 1920 um neue Fakten ergänzt.

Plebiscyt na Powiślu, Warmii i Mazurach był wypadkową obrad konferencji pokojowej w Paryżu w 1919 r. ${ }^{1}$. Obowiązek jego przeprowadzenia wynikał wprost z zapisu Traktatu wersalskiego, z działu VIII dokumentu - paragrafów 94-97². Już wkrótce po ogłoszeniu postanowień pokojowych, na terenach plebiscytowych rozpoczęły się przygotowania do agitacji. Przedstawiciele różnych środowisk, w tym także rodzin ziemiańskich, których majątki znajdowały się na Powiślu, z zaangażowaniem podjęli różne działania, aby plebiscyt, zapowiedziany ostatecznie na 11 lipca 1920 r., został rozstrzygnięty na korzyść Polski.

Polskie interesy miał reprezentować Warmiński Komitet Plebiscytowy (WKP), powołany przez władze Rzeczypospolitej 3 sierpnia 1919 r. na mocy dekretu Rady Ministrów. Pierwotnie kierował nim Brunon Gabrylewicz, który został w listopadzie $1919 \mathrm{r}$. aresztowany w związku z bezpodstawnym, jak się później okazało, podejrzeniem o współpracę z wywiadem niemieckim i działalność przeciwko Polsce. W grudniu nastąpiła zmiana władz, a komitetem pokierowali, początkowo Stanisław Nowakowski, od stycznia 1920 r. ziemianin Kazimierz Donimirski z Małych Ramz, a kilka miesięcy później ks. Antoni Ludwiczak³.

$1 \quad$ Decyzja mocarstw o plebiscycie na Powiślu, Warmii i Mazurach była w pewnym sensie porażką delegacji polskiej na konferencji pokojowej w Paryżu. Oficjalne stanowisko w kwestii zachodniej granicy Polski z 28 II 1919 r. zakładało odłączenie Prus Wschodnich od państwa niemieckiego i rozczłonkowanie tej prowincji między Polskę (Powiśle, Warmia, Mazury) i Litwę (ujście Niemna z Kłajpedą). Z pozostałej, zamieszkałej przez Niemców części Prus Wschodnich miano powołać republikę pod protektoratem Ligi Narodów, zob. - R. Kempa, Mazurskie reminiscencje rocznicowe. Powiat giżycki w 90. rocznice plebiscytu, w: Białostockie Teki Historyczne, Białystok 2010, t. 7, s. 124-126.

2 Traktat pokoju między mocarstwami sprzymierzonemi i skojarzonemi i Niemcami, podpisany w Wersalu dnia 28 czerwca 1919 roku (źródło: http://isap.sejm.gov.pl/isap.nsf/DocDetails.xsp?id=WDU19200350200; dostęp: 2 XI 2020 r.).

3 Memoriał St. Nowakowskiego i J. Czodrowskiego do Komisariatu Naczelnej Rady Ludowej w Poznaniu w spra- 
WKP kierował akcją wyborczą poprzez organizację różnych spotkań, wieców, kultywowanie tradycji narodowych. Zarząd starał się być elastyczny w swoich działaniach i wykorzystywać narzędzia, z pomocą których dałoby się dotrzeć do każdego, bez względu na wiek lub zainteresowania, co może świadczyć o tym, iż ogromne znaczenie przywiązywano do mobilizacji społeczeństwa. WKP pozostawał w stałym kontakcie z polskim Ministerstwem Spraw Zagranicznych. Na ile jednak ten stały kontakt przekładał się na konkretne wsparcie działań WKP w terenie, trudno dziś jednoznacznie ocenić ${ }^{4}$. W literaturze dotyczącej plebiscytu na Powiślu, Warmii i Mazurach opinia dotycząca działań władz państwa polskiego oceniana jest negatywnie. Przeważa pogląd, iż kierownictwo polskiej polityki zagranicznej nie wykazało należytej inicjatywy w wysuwaniu politycznych koncepcji ani nie posiadało jednolitego od początku programu w sprawie ziem północnych ${ }^{5}$. Sytuację dodatkowo utrudniała zła sytuacja kraju, ze względu na toczącą się wojnę polsko-bolszewicką ${ }^{6}$.

Jednak w obliczu trudnych wydarzeń politycznych próbę zainteresowania polskiej opinii publicznej sprawami plebiscytowymi podjął dr Stefan Dąbrowski. Wszedł on w skład polskiego rządu jako podsekretarz stanu w Ministerstwie Spraw Zagranicznych 2 kwietnia 1920 r. Jego nominacja spotkała się z powszechnym sceptycyzmem. Był specjalistą chemikiem, biochemikiem, profesorem medycyny, specjalizował się w badaniach fizjologii i nauki żywienia. Bardzo krytycznie oceniano jego brak przygotowania i doświadczenia dyplomatycznego, potrzebnego na tym stanowisku $\mathrm{u}^{7}$. Zaangażowanie się $\mathrm{w}$ prace związane $\mathrm{z}$ przygotowaniami do plebiscytu były pierwszym krokiem Stefana Dąbrowskiego na stanowisku wiceministra spraw zagranicznych. Sytuację na tych terenach nowy wiceminister oceniał jako bardzo trudną, zaś celem agitacji w duchu propolskim było stworzenie publikacji o charakterze informacyjno-propagandowym dla całego kraju ${ }^{8}$. Z inicjatywy

wie utworzenia Warmińskiego Komitetu Plebiscytowego, w: Plebiscyt na Warmii, Mazurach i Powiślu w 1920 r. Wybór źródeł, (dalej: Plebiscyt...), red. P. Stawecki i W. Wrzesiński, Olsztyn 1986, s. 61; Pismo Warmińskiego Komitetu Plebiscytowego do Podkomisariatu Naczelnej Rady Ludowej..., w: Plebiscyt..., s. 68; Z listu St. Sierakowskiego do żony H. Sierakowskiej..., w: Plebiscyt..., s. 97; Pismo Sekretarza generalnego Rady Narodowej w Poznaniu M. Korzeniewskiego do Prezydium Rady Ministrów..., w: Plebiscyt..., s. 125.

4 Dla przykładu 11 VI 1920 r. przewodniczący WKP ks. Ludwiczak wysłał do Ministra Spraw Zagranicznych Wróblewskiego telegram o treści: „Plebiscyt za pasem. Pieniądze natychmiast potrzebne. Nie mam ani feniga”, Telegram szyfrowy $\mathrm{nr} 7 \mathrm{ks}$. A. Ludwiczak do Ministerstwa Spraw Zagranicznych w Warszawie o sytuacji materialnej Warmińskiego Komitetu Plebiscytowego, w: Plebiscyt..., s. 61.

W. Wrzesiński, Prusy Wschodnie w polskiej myśli politycznej 1864-1945, Olsztyn 1994, s. 207 i n.; W. Wrzesiński, Polska - Prusy Wschodnie. Plebiscyty na Warmii i Mazurach oraz na Powiślu w 1920 roku (dalej: Polska - Prusy...), Olsztyn 2010, s. 284.

6 A. Barganowski, Plebiscyt na Powiślu, Elbląg 1989, s. 128.

J. Malinowski, Stefan Dąbrowski (1877-1947). Biografia polityczna, Poznań 2014, s. 103.

8 J. Malinowski, Działalność Stefana Dąbrowskiego w związku z plebiscytami na Powiślu, Warmii i Mazurach w 1920 roku, „Komunikaty Mazursko-Warmińskie”, 2011, nr 4 (274), s. 706. 
Dąbrowskiego Warmiński Komitet Plebiscytowy zaczął realizować program spotkań z ludźmi świata kultury, literatury i sztuki. Artyści mieli wpływać na poczucie więzi z krajem wśród mieszkańców ziemi nadwiślańskiej oraz popularyzować priorytetowy charakter wydarzeń na terenie Prus w Polsce, rozbudzając zainteresowanie sprawami plebiscytu.

Takim działaniem była wizyta trzech polskich literatów w nadwiślańskich powiatach: Stefana Żeromskiego, Jana Kasprowicza i Władysława Kozickiego9. Warto zadać pytanie, dlaczego wybrano akurat taką reprezentację? Pewną wskazówką mogą być wątki z życiorysów wspomnianych postaci. Pomysłodawca wyjazdu wtedy jeszcze doktor nauk medycznych Stefan Dąbrowski, po ukończeniu studiów kontynuował pracę naukową na Uniwersytecie Lwowskim, ale prowadził także działalność polityczną. Dzięki tej aktywności znał doskonale Jana Kasprowicza, Stefana Żeromskiego i Władysława Kozickiego. Wspólną cechą, łączącą wszystkie powyższe postacie był fakt, iż wszyscy byli członkami Ligi Narodowej, działającej od 1 kwietnia 1893 r. - ruchu skupionego wokół Romana Dmowskiego. Ta organizacja stała się podstawą funkcjonowania późniejszego obozu politycznego Narodowej Demokracji. Już w początkach XX w. Dąbrowski w Zakopanem brał udział w spotkaniach politycznych, realizowanych przez Kasprowicza i Żeromskiego (tzw. grupa ententofilska). Zresztą dzięki Kasprowiczowi, Dąbrowski poznał samego W. Lenina. Poza Żeromskim, Dąbrowski, Kasprowicz i Kozicki byli członkami tzw. grupy lwowskiej Ligi Narodowej ${ }^{10}$.

Jan Kasprowicz mieszkał we Lwowie od 1889 r. Pracował dla „Kuriera Lwowskiego" oraz "Słowa Polskiego" pisząc artykuły literackie, polityczne o zaborze pruskim, sprawozdania sądowe. W 1904 r. doktoryzował się na Uniwersytecie Lwowskim, gdzie od 1909 r. objął katedrę komparatystyki literackiej ${ }^{11}$.

Władysław Kozicki z kolei był rodzonym lwowiakiem. Studiował historię sztuki, uzyskał doktorat z filozofii. Pracował jako pracownik naukowy na Uniwersytecie Jana Kazimierza we Lwowie. Był wieloletnim konserwatorem zabytków sztuki we Lwowie, wydał szereg rozpraw $\mathrm{z}$ historii sztuki, zajmował się także literaturą. Był krytykiem i recenzentem wystaw malarstwa współczesnego i rzeźby, ale także

9 Niektóre opracowania błędnie podają skład delegacji często wymieniając Stanisława Kozickiego - publicystę i członka polskiej delegacji w Wersalu, zamiast Władysława Kozickiego - literata, dziennikarza, np. Z. Lietz, Plebiscyt na Powiślu, Warmii i Mazurach w 1920 roku, Warszawa 1958, s. 192; W. Wrzesiński, Polska - Prusy..., s. 378; A. Barganowski, op. cit, s. 106; idem: Plebiscyt na Ziemi Kwidzyńskiej, w: Plebiscyt na Powiślu - 11 lipiec 1920 rok, „Zeszyty Kwidzyńskie", nr 1, Kwidzyn 2000, s. 6-91.

10 J. Malinowski, Działalność polityczno- społeczna prof. Stefana Dąbrowskiego (1877-1947), Uniwersytet im. A. Mickiewicza w Poznaniu, Poznań 2012, s. 38 i 59 (źródło: https://repozytorium.amu.edu.pl/bitstream/10593/2650/1/ Dzia\%C5\%82alno\%C5\%9B\% C4\%87\%20 polityczno- spo\%C5\%82eczna\%20prof.\%20Stefana\%20D\%C4\%85browskiego.pdf; dostęp: 2 XI 2020 r.]; Liga Narodowa (1893-1928). Wybór relacji, opr. T. Sikorski, A.Wątor, Warszawa 2015, s. 16.

${ }_{11}$ Obszerny życiorys Jana Kasprowicza: Z. Wasilewski, Wspomnienia o Janie Kasprowiczu i Stefanie Żeromskim, Warszawa-Kraków-Lublin-Łódź-Paryż-Poznań-Wilno-Zakopane, 1927, s. 10 i n. 
recenzentem teatralnym. Znali się z Janem Kasprowiczem ze wspólnej działalności we Lwowie - głównym ośrodku polskiego modernizmu. Jednym ze znanych ognisk życia literackiego był dom M. i W. Wolskich na Zaświeciu. Tę towarzyską grupę literatów Lwowa nazywano żartobliwie Płanetnikami. Kozicki dzięki J. Kasprowiczowi stał się współpracownikiem (a wkrótce członkiem redakcji) „Słowa Polskiego” (do 1927 r.), obejmując po W. Witwickim referat sztuk plastycznych ${ }^{12}$.

Stefan Żeromski znał się doskonale z Janem Kasprowiczem jeszcze od końca lat 90. XIX w. W latach 1914-1916 obaj byli członkami tajnej organizacji niepodległościowej. Obaj panowie bardzo często spotykali się w Zakopanem, także w szerszym gronie literatów (ze względów zdrowotnych Żeromski mieszkał w Zakopanem w latach 1903-1905 i 1909-1910). Obaj współtworzyli Rzeczpospolitą Zakopiańską - symboliczny twór państwowy istniejący w 1918 r. przez 35 dni na terenie Zakopanego i okolic. Żeromski bywał zresztą również we Lwowie. Poza więc oficjalnym ruchem na rzecz wsparcia plebiscytu, wybór składu delegacji nie był przypadkowy. Atutem dodatkowym w tym przypadku była popularność pisarzy: nazwiska powszechnie znane Polakom, ich autorytet pisarski i społeczny mógł wzmocnić akcję propagandową, a co za tym idzie, zwiększyć szansę na pomyślny wynik plebiscytu ${ }^{13}$.

Niewątpliwie warto zwrócić uwagę na jeszcze jeden fakt. W lutym 1920 r., w Warszawie, zawiązany został specjalny komitet, na czele którego stanęła Stanisława Wysocka - polska aktorka, reżyser teatralny. W skład tego komitetu wszedł również Stefan Żeromski. Zadaniem tegoż komitetu miało być nakręcenie filmu na rzecz ziem plebiscytowych, obrazujące Polskę jako potęgę gospodarczą, społeczną, moralną. Do realizacji filmu nigdy nie doszło, ale to pokazuje, iż pomysł odwołania się „ludzi świata kultury” do społeczności Warmii, Mazur i Powiśla w jakiejkolwiek formie, pojawił się w zasadzie już w początkach $1920 \mathrm{r}^{14}$.

Poza wizytą na terenach plebiscytowych trzech literatów Stefan Dąbrowski zwrócił się także o pomoc i współpracę do artysty malarza Władysława Jarockiego. Malarz prywatnie był zięciem Jana Kasprowicza, zaś w ramach działań Ministerstwa miał zająć się zaprojektowaniem plakatu promującego głosowanie na terenach spornych $^{15}$. Najprawdopodobniej Władysław Jarocki nie wywiązał się z tego zadania lub nawet nie podjął, gdyż do dziś nigdzie nie ma żadnej wzmianki na ten temat. Wiadomo jednak, że także był w Kwidzynie, ale o tym w dalszej części niniejszego tekstu.

12 B. Szynkarczyn, Kilka słów o Władysławie Kozickim, „Schody Kawowe”, nr 1/45 (Rok XII), 2011, s. 21.

13 Obszerny życiorys Stefana Żeromskiego: Z. Wasilewski, op. cit. s. 115 i n.; B. Szynkarczyn, Krótki rys o Stefanie Żeromskim, „Schody Kawowe”, nr 4/44 (Rok XI), 2010, s. 20-21.

14 Ze sprawozdania z posiedzenia Komisji Wykonawczej Komitetu Mazurskiego, omawiającego sprawy organizacyjne i nakręcenia filmu na rzecz ziem plebiscytowych, w: Plebiscyt..., s. 135.

15 J. Malinowski, Stefan Dąbrowski..., Poznań 2014, s. 108. 
Stefan Żeromski, Jan Kasprowicz i Władysław Kozicki przybyli do Kwidzyna 21 maja 1920 r. $^{16}$ samochodem, w towarzystwie urzędnika Polskiego Konsulatu w Kwidzynie Tadeusza Morawskiego ${ }^{17}$, zapewne w celu uniknięcia problemów z przekroczeniem granicy. Zaopatrzeni byli w listy polecające skierowane m.in. do komisarza generalnego RP w Gdańsku Macieja Biesiadeckiego i do p.o. konsula generalnego w Olsztynie Czesława Andrycza. Wyruszyli na Powiśle jako wysłannicy rządu polskiego, zaś wszelkie koszty związane z podróżą i pobytem ponosił Główny Komitet Plebiscytowy przy Radzie Ministrów, pracujący pod kierunkiem wiceministra Władysława Wróblewskiego ${ }^{18}$. W małym muzeum, tzw. Domku Żeromskiego w Gdyni, zachowała się informacja, iż Żeromski wraz z żoną Anną i siedmioletnią córką przebywali w Gdyni od początków maja. Poeta do Kwidzyna miał wyjechać 20 maja. Tekst Inter Arma rozpoczyna się od informacji podróżnej, o pociągu jadącym z Tczewa do Grudziądza ${ }^{19}$. Można więc wysnuć wniosek, że członkowie delegacji spotkali się w Grudziądzu (dokąd wszyscy dotarli koleją Żeromski z Gdyni, zaś Kasprowicz i Kozicki z Warszawy), a stąd z kolei odebrał delegację pracownik konsulatu i razem dalszą drogę odbyli samochodem. O tym, że mogła nastąpić „krótka przerwa” w podróży do Kwidzyna może poświadczyć notatka, zawarta w wywiadzie z J. Kasprowiczem, wydrukowana z „Gazecie Warszawskiej” z czerwca 1920 r., w którym autor pisze: zatrzymaliśmy się na krótko w Grudziądzuㄹ ${ }^{20}$.

Pomimo - wydawałoby się - skrupulatnego opisu podróży przez Żeromskiego w Inter Armie, którą autor publikuje jako małą książeczkę jeszcze w tym samym, 1920 r., trudno odtworzyć chronologiczny przebieg całej wizyty delegacji. Poza krótką notką o przyjeździe do Kwidzyna, zawartą w „Gazecie Polskiej dla Powiatów Nadwiślańskich” - prasowym organie Warmińskiego Komitetu Plebiscytowego, nie ma żadnych artykułów o pobycie gości na Powiślu. Szczegółowa relacja ukazuje się na łamach tej gazety dopiero pod koniec maja i jest to relacja już z pobytu 30 maja w Olsztynie. 29 maja zapowiedź przyjazdu wydrukowana jest $\mathrm{w}$ formie krótkiej informacji w „Gazecie Olsztyńskiej”"21, gdzie delegacja „zaanonsowana”

16 Wiele opracowań podaje przybliżoną lub błędną datę przyjazdu delegacji do Kwidzyna. Źródłem nie pozostawiającym wątpliwości jest miejscowa gazeta, która opublikowała krótką notkę, opatrzoną datą, zob. - Z bliska i z daleka, „Gazeta Polska dla Powiatów Nadwiślańskich”, R. I, nr 45, 22 V 1920, s. 3.

17 Tadeusz Morawski został skierowany do pracy w Konsulacie w Kwidzynie przez Ministerstwo Spraw Zagranicznych jako zastępca delegata rządu polskiego do spraw plebiscytowych, był także członkiem Warmińskiego Komitetu Plebiscytowego: M. Żerebny, Kasprowicz w 1920 roku na Powiślu i Warmii, w: Jan Kasprowicz w siedemdziesięciolecie śmierci, Materiały Międzynarodowej Sesji Naukowej Olsztyn 17-19.X.1996, red. J. Kaczyński, Olsztyn 1999, s. 236; S. Żeromski, Inter Arma, Warszawa-Kraków, 1920, s. 20.

18 J. Malinowski, Stefan Dąbrowski..., s. 108.

19 S. Żeromski, op. cit., s. 18.

20 Szanse plebiscytowe. Wywiad z Janem Kasprowiczem, cz. 1, „Gazeta Warszawska”, R. 140, Nr 153, 7 VI 1920, s. 1.

${ }_{21}$ Żeromski i Kasprowicz w Olsztynie, „Gazeta Olsztyńska”, R. 34, nr 64, 29 V 1920, s. 2. 
została w składzie: Jan Kasprowicz i Stefan Żeromski. Jednak z „Gazety Polskiej dla Powiatów Nadwiślańskich” wiemy z całą pewnością, że do Olsztyna dojechali automobilem Jan Kasprowicz i Władysław Kozicki w towarzystwie ks. Antoniego Ludwiczaka. Wszyscy wzięli udział w spotkaniu Towarzystwa Ludowego w Domu Polskim, na którym poeta wygłosił przemówienie. Wieczorem powrócili do Kwidzyna, w drodze powrotnej odwiedzając ludowego poetę warmińskiego Andrzeja Samulowskiego w Gietrzwałdzie ${ }^{22}$.

Wróćmy jednak do wizyty na terenie kwidzyńskiego okręgu plebiscytowego. Porównując zachowane informacje z miejscowej gazety oraz nakładając na to opis podróży po powiślańskich miejscowościach w Inter Armie, można częściowo ułożyć chronologię pobytu Stefana Żeromskiego, Jana Kasprowicza i Władysława Kozickiego na Powiślu. Zaraz po przyjeździe do Kwidzyna, 21 maja 1920 r., goście zwiedzili stare miasto, rynek oraz zespół katedralno-zamkowy, obchodząc budowlę wokół. Zabytek nie zrobił jednak na Żeromskim większego wrażenia, choć poświęcił mu w swym reportażu wręcz demoniczny opis:

Gdyby ktoś nie znat dziejów komturstwa w Marienwerder, nie wiedziat wcale, w jakim celu wzniesione zostaty te strome budowle [...] to ta dziwna forteca, odpychajaca swym ponurym kształtem, wyjawiłaby mu sama dokładna powieść o pobożnych ujarzmicielach. Kolosalne murowane nogi zamczyska, wychodzące z kompleksu murów kościoła, twierdza czyhająca na ślepych i nagich murach, na olbrzymich zrudzialych i zzielenialych skarpach, caly ten murowany rynsztunek zbója zdaje się przyklękać do skoku na daleką, płaską ziemię Powiśla ${ }^{23}$.

Żeromski, podobnie jak wcześniej w Grudziądzu, próbuje dokonać analizy społecznej miasta:

Miasto rozpostarte dookoła zamczyska i kościoła nosi dziś charakter czysto niemiecki. Ani jednego napisu polskiego - z wyjatkiem kartek ogłoszenia komisyi plebiscytowej... [...] każda prywatna rozmowa, prowadzona na ulicy po polsku, wywotuje odruch spojrzenia, które, gdyby tylko mogło, gotowe by blizniego w tyżce wody utopic ${ }^{24}$.

Goście korzystali z rozmów z „miejscowymi”, wieczorem lokując się w Hotelu Cassino przy ówczesnej Marienburgerstrasse. 22 maja panowie odwiedzili Konsulat Polski, gdzie wzięli udział w spotkaniu z konsulem hr. Stanisławem Sierakowskim,

22 Jan Kasprowicz w Olsztynie, „Gazeta Polska dla Powiatów Nadwiślańskich”, R. I, nr 55, 5 VI 1920, s. 3.

23 S. Żeromski, op. cit., s. 20.

24 Ibidem, s. 22. 
a następnie $\mathrm{w}$ posiedzeniu komitetu plebiscytowego (m.in. z udziałem Rudolfa Nowowiejskiego - brata kompozytora i autora Roty Feliksa Nowowiejskiego). 23 maja ma miejsce spotkanie z przedstawicielami Międzysojuszniczej Komisji Plebiscytowej, gdzie m.in. goście omawiali niedawne zajścia w Kwidzynie, związane $\mathrm{z}$ brutalnym rozbiciem przez Niemców polskiego wiecu w dniu 16 maja ${ }^{25}$. Rozmawiali z przewodniczącym Angelo Pavią, Henrym Beaumontem oraz Rene de Charizeyem ${ }^{26}$. Wydaje się, że te pierwsze trzy dni pobytu, to raczej swego rodzaju część oficjalna, mocno polityczna. Szereg spotkań na szczeblu instytucji, zapoznanie się z ogólną sytuacją, wreszcie spotkania z członkami Międzysojuszniczej Komisji Plebiscytowej i innych oficjalnych struktur. Wszak zacni goście byli wysłannikami i przedstawicielami polskiego rządu. Może z tego właśnie powodu Żeromski opisuje dokładnie także miejsca, w których ogniskuje się działalność Polaków, ale także dokonuje oceny działalności członków komisji alianckiej:

odnosiło się wrażenie, iż zawzięty, zimny $i$ ironiczny Anglik Beaumont nie jest wcale przyjacielem naszej sprawy na tej ziemi plebiscytowej, natomiast przedstawiciel Francyi sprzyja nam bezwzględnie ${ }^{27}$.

24 maja delegaci wzięli udział w wielkim wiecu polskim, zorganizowanym w Kwidzynie, na którym przemawiał Jan Kasprowicz. Aż dwie i pół strony autor Inter Army poświęcił na opis wiecu, atmosfery i ludzi, którzy przyszli w nadziei wysłuchania mowy polskiej, informacji politycznych oraz wzięcia udziału po prostu $\mathrm{w}$ wiecu wyborczym ${ }^{28}$. Nazajutrz planowany był wyjazd do Iławy, który ostatecznie nie doszedł do skutku. Cała trójka (tj. Kasprowicz, Żeromski i Kozicki) razem z Tadeuszem Dykierem miała udać się na podobny wiec. Do wyjazdu nie doszło, ponieważ szofer (Niemiec) mający zawieść wspomnianych agitatorów do Iławy, nie przyjechał po nich do Kwidzyna pod pozorem awarii samochodu. Wiec odbył się więc bez znamienitych gości. Można w tym miejscu zauważyć, iż Niemcy, prowadząc takie kontrakcje na bieżąco i sprawnie, przygotowani byli na różne scenariusze na terenach plebiscytowych ${ }^{29}$.

Kolejnego dnia delegaci w towarzystwie ks. Antoniego Ludwiczaka odwiedzili Sztumską Wieś, Sztum, Malbork, następnie w drodze powrotnej pojechali do Zajezierza - majątku Donimirskich, a stamtąd wrócili na wiec polski do Sztumu, skąd jak pisze Żeromski wymknęli się cichcem $z$ rozbawionego tlumu i samowtór z moim

\footnotetext{
5 Komunikat Polskiej Agencji Telegraficznej o napadzie Niemców na pochód polski w Kwidzynie, w: Plebiscyt..., s. 302.

26 S. Żeromski, op. cit., s. 27.

7 Ibidem, s. 27.

28 Wiec wywarł głębokie wrażenie na Żeromskim, co przebija z opisu tego zdarzenia, ibidem, s. 27-29.

29 Ibidem, s. 30.
} 
poeta, pomknęli do Kwidzyna ${ }^{30}$. Pisarz, opisując wizytę w Zajezierzu, jako właściciela majątku błędnie wskazał Kazimierza zamiast Augusta Donimirskiego ${ }^{31}$. Jednoznacznie wynika też z opisu, że w tym dniu nie podróżował W. Kozicki, co potwierdza autor już kilka zdań dalej, pisząc: polami niósł nas samochód, dwu fantastów... 26 maja dzień rozpoczął się od wizyty w Górkach pod Kwidzynem u Państwa Kowalskich. Raczej nie nocowali jeszcze tutaj, gdyż autor nie zawarł żadnego opisu ponad: $z$ gościnnego domu państwa Kowalskich [...], gdzie wkrótce utworzyła się kwatera główna komitetu, udaliśmy się z druga z kolei drogę... Literaci podróżowali do wschodniej części Powiśla w towarzystwie Rudolfa Nowowiejskiego - do Iławy, Prabut i Susza, skąd w drodze powrotnej wszyscy zajechali do Bukowa (Buchwałdu) - do majątku Donimirskich, a następnie do Waplewa Wielkiego - majątku Sierakowskich. Na tym relacja Stefana Żeromskiego na kartach Inter Army kończy się. Każdy dzień musiał być wypełniony spotkaniami, zaś majowe $w$ ciemności nocnej migające wsie $e^{32}$, wskazują, że na miejsce noclegu goście powracali bardzo późno.

Trudno prześledzić precyzyjnie dalszy przebieg wizyty Stefana Żeromskiego, Jana Kasprowicza i Władysława Kozickiego na terenach plebiscytowych. Można powiedzieć, iż panowie nie wszędzie podróżowali razem. Być może z powodu ograniczonego miejsca w automobilu. Tego się jednak nie dowiemy.

Jest jeszcze jeden ślad, który można dopisać do chronologii podróży polskiej delegacji. Mianowicie jedyne znane dziś zdjęcie delegacji, wykonane w majątku Górki u Cecylii i Jana Kowalskich, a zachowane w zbiorach rodzinnych wnuka właścicieli - Ryszarda Zamojskiego. Na fotografii, na pierwszym planie widnieje przykucnięty Tadeusz Dykier - sekretarz Warmińskiego Komitetu Plebiscytowego (kilka miesięcy wcześniej porzucił stan duchowny), siedzą od prawej: Stefan Żeromski, Jan Kasprowicz, Władysław Kozicki, za nimi stoją od prawej: Jan Ornass, [nn], Jan Kowalski, Kazimierz Kowalski (młodszy brat Jana). Panom towarzyszy dwoje dzieci Jana Kowalskiego. Ów kadr w zbiorach rodzinnych wnuka Jana Kowalskiego występuje $\mathrm{w}$ dwóch odsłonach: pierwszy egzemplarz jest podpisany autografami trzech literatów bezpośrednio na zdjęciu. Drugie zdjęcie, zostało naklejone na większą kartę, na której każdy z gości wpisał pamiątkowy tekst. Dedykacje wraz z datami jednoznacznie wskazują, że w tym czasie literaci nocowali w majątku, w Górkach (w owej kwaterze głównej komitetu jak pisał Żeromski). W przypadku Kozickiego dedykacja została datowana na 28 maja, wiersz napisany przez Jana Kasprowicza opatrzony został datą 1 czerwca 1920 r. Zapis zaś Żeromskiego: Pod nieobecność Szanownej Gospodyni zakwaterowaliśmy się w Górkach, jak $w$ rodzinnym domu $i$ wiele chwil prawdziwie miłych spędziliśmy tutaj... wskazuje,

30 Ibidem, s. 40.

31 Ibidem, s. 37.

32 Ibidem, s. 40 . 


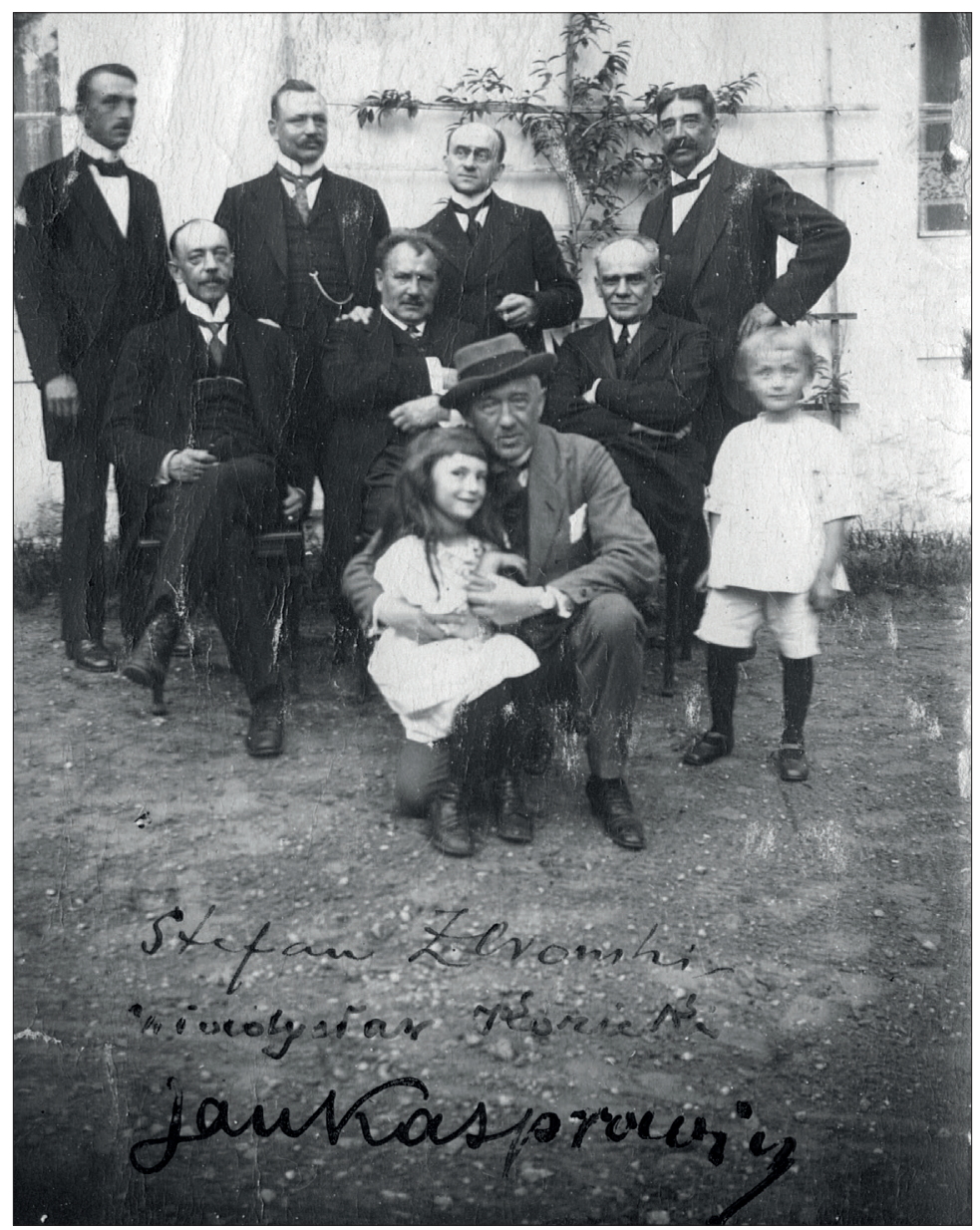

Wizyta literatów w Górkach - majątku rodziny Kowalskich, 2 czerwca 1920 r. Na pierwszym planie Tadeusz Dykier, dwoje dzieci Jana i Cecylii Kowalskich, siedzą od prawej: Stefan Żeromski, Jan Kasprowicz, Władysław Kozicki; stoją od prawej: Jan Ornass, (nn), Jan Kowalski, Kazimierz Kowalski. fot. archiwum wnuka Kowalskich Ryszarda Zamojskiego.

iż po 26 maja Panowie zamieszkali w Górkach. Można założyć, że po porannej, pierwszej wizycie u rodziny Kowalskich, gospodarz zaprosił znamienitych gości na dłuższy pobyt w gościnnych progach własnego dworku.

Wydawałoby się, że jedyną relacją z pobytu literatów na Powiślu jest tekst Inter Army. Większość opracowań powołujących się na wizytę Kasprowicza, Żeromskiego oraz Kozickiego opiera się wyłącznie na analizie małej książeczki Żeromskiego. Warto jednak zauważyć, że źródłem dotyczącym misji na Powiślu jest także wywiad udzielony przez Jana Kasprowicza „Gazecie Warszawskiej”, w dwóch 
częściach, w następujących po sobie wydaniach gazety z dnia 7 i 8 czerwca 1920 r. $^{33}$. Poeta, zdając relację z wyjazdu, potwierdza chronologię, wynikającą z tekstu Żeromskiego. Potwierdza również kilkudniowy pobyt w dworku, w Górkach. Interesującym z punktu widzenia przebiegu wizyty literatów może być fakt, że wywiad zamieszczony w „Gazecie Warszawskiej”, ukazał się 7 czerwca, zaś J. Kasprowicz pisze także, iż: polskość Grudziądza zamanifestowała się wspaniale przed kilku dniami, gdyśmy wracali do Warszawy. Był dzień Bożego Ciała. Autor przeprowadzonego wywiadu zaznacza również, że korzysta $z$ kilkudniowego pobytu Jana Kasprowicza $w$ Warszawie. Mowa więc bezsprzecznie o dniu 3 czerwca 1920 r. Ewidentnie wskazuje to na nieznany i pomijany dotąd fakt, że Kasprowicz i Kozicki jeździli do Kwidzyna dwa razy - a nie jak dotąd uważano - tylko jeden raz ${ }^{34}$. „Gazeta Polska dla Powiatów Nadwiślańskich” poinformowała z kolei w krótkiej notatce 16 czerwca, że Kasprowicz i Kozicki opuszczają Kwidzyn. Goście wyjechali do Gdańska ${ }^{35}$. Kiedy wyjechał więc Żeromski? Z notatki w małym muzeum tzw. Domku Żeromskiego w Gdyni dowiadujemy się, iż Żeromski powrócił nad morze do Gdyni już 2 czerwca. Prawdopodobnie 16 czerwca Kasprowicz i Kozicki pojechali właśnie do małego domku nad morzem, w odwiedziny do Państwa Żeromskich.

$\mathrm{Z}$ wywiadu z Janem Kasprowiczem dowiadujemy się jeszcze jednej ciekawostki, mianowicie o wizycie literatów w Gniewie, cyt. W Gniewie - informowat dalej J. Kasprowicz - znaleźliśmy gościnę u miejscowego starosty p. Czarnowskiego ${ }^{36}$. Informacja zaskakująca o tyle, że Gniew w 1920 r. leżał już w granicach Polski i aby dostać się do miasteczka trzeba było już przekraczać granicę. Czy można zatem założyć, że skoro literaci podróżowali po Powiślu samochodem, do Gniewu musieli jechać przez most na Wiśle pod Kwidzynem i granicę przekraczać w Opaleniu? Tego, na podstawie tak skąpej informacji nie da się uwiarygodnić.

Jak chronologicznie osadzić drugą wizytę na Powiślu? Znamy tylko datę wyjazdu z Kwidzyna 16 czerwca. Z tą częścią wizyty łączy się jeszcze jedna ciekawa, nieznana dotąd informacja. W zbiorach prywatnych wnuka Jana Kowalskiego właściciela majątku Górki znajduje się sporej wielkości szkic, wykonany ołówkiem. Przedstawia postać siedzącego Jana Kasprowicza. Obok sylwetki po obu stronach znajdują się dedykacje. Pierwsza z nich brzmi:

Gdy Polska przyjdzie do Ciebie, wspomnij mój Janku kochany Tych, którym było jak w niebie, Gdyś Domu otworzyt im ściany. W Górkach 14.VI. 1920. Władystaw Kozicki.

33 Szanse plebiscytowe. Wywiad z Janem Kasprowiczem, cz. I, „Gazeta Warszawska”, R. 140, nr 153, 7 VI 1920, s. 1; Szanse plebiscytowe, wywiad z Janem Kasprowiczem, cz. II, „Gazeta Warszawska”, R. 140, nr 154, 8 VI 1920, s. 2.

${ }^{34} \mathrm{Z}$ pewnością pełne odtworzenie trasy oraz chronologii pobytu Stefana Żeromskiego, Jana Kasprowicza i Władysława Kozickiego na Powiślu wymaga dalszych badań.

${ }_{35}$ Z bliska i z daleka, „Gazeta Polska dla Powiatów Nadwiślańskich”, R. I, nr 66, 18 VI 1920, s. 4.

${ }^{36}$ Szanse plebiscytowe..., cz. II. 


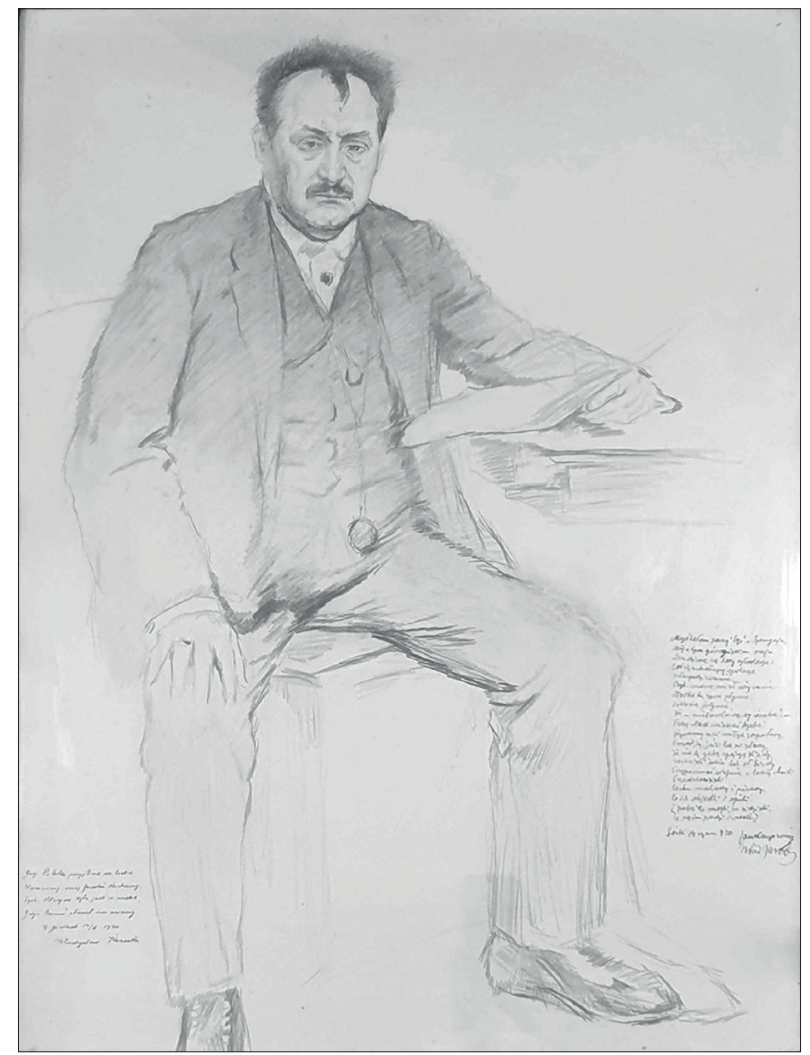

W czerwcu 1920 roku w Górkach - majątku rodziny Kowalskich wizytował Władysław Jarocki, prywatnie zięć Jana Kasprowicza. Artysta namalował portret teścia, na którym dopisane zostały po bokach dedykacje Władysława Kozickiego, Jana Kasprowicza i Władysława Jarockiego. Portret Kasprowicza znajduje się w rękach prywatnych - wnuka Kowalskich Ryszarda Zamojskiego. Fot. Justyna Liguz

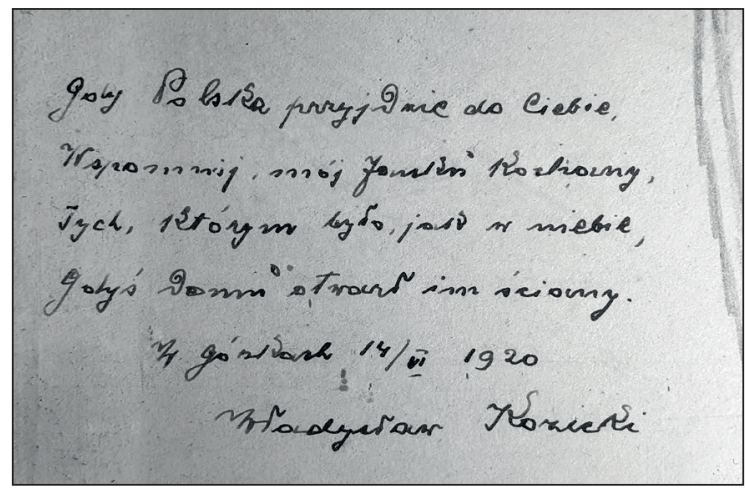

Dedykacja Władysława Kozickiego z 14 czerwca 1920 roku, napisana u boku szkicu Władysława Jarockiego, przedstawiającego Jana Kasprowicza. Portret Kasprowicza znajduje się w rękach prywatnych - wnuka Kowalskich Ryszarda Zamojskiego. Fot. Justyna Liguz 


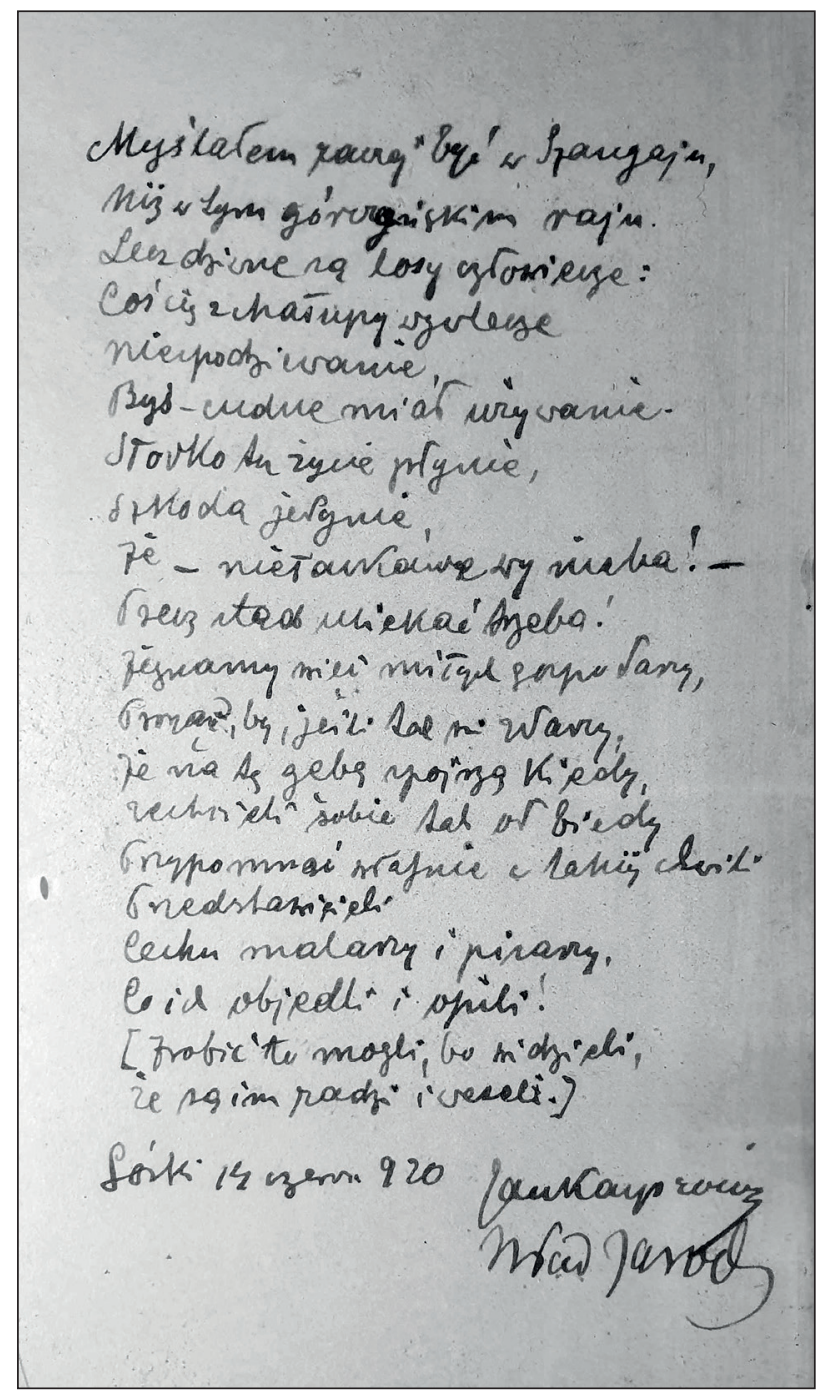

Dedykacja z 14 czerwca 1920 roku, napisana u boku szkicu Władysława Jarockiego, przedstawiającego Jana Kasprowicza. Portret Kasprowicza znajduje się w rękach prywatnych wnuka Kowalskich Ryszarda Zamojskiego. Fot. Justyna Liguz

Drugi wpis jest nieco dłuższy:

Myślałem raczej być $w$ Szangaju, niż w tym górczańskim raju. Lecz dziwne sa losy człowiecze: Coś Cię z chałupy wywlecze niespodziewanie, Byś - cudne miał używanie. Słodko tu życie płynie, szkoda jedynie, że - niełaskawe wy nieba! - Precz stąd uciekać trzeba! Żegnamy więc mitych gospodarzy, Prosząc, 
by, jeśli tak się zdarzy, że na tę gębę spojrza kiedy, zechcieli sobie tak od biedy, przypomnieć właśnie w takiej chwili przedstawicieli Cechu malarzy i pisarzy. Co ich objedli i opili. [Zrobić to mogli, bo wiedzieli, że sa im radzi i weseli.] Górki 14 czerwca 920 Jan Kasprowicz Władystaw Jarock $i^{37}$.

Z tej dedykacji wynika niezbicie, iż podczas drugiej podróży do Kwidzyna do Kasprowicza i Kozickiego dołączył... Władysław Jarocki. Zachowało się jeszcze jedno źródło, które to potwierdza, mianowicie tekst Władysława Kozickiego, opublikowany w „Gazecie Warszawskiej”, w którym m.in. czytamy:

prezydent rady ministrów zwrócił się z inicjatywy dr. Dąbrowskiego do Jana Kasprowicza, Stefana Żeromskiego i podpisanego z zaproszeniem do odbycia podróży po pótnocnych terenach plebiscytowych, celem naocznego poznania tych obszarów, wyczucia nastrojów miejscowych i podzielenia się odniesionemi wrażeniami $z$ Polakami $w$ kraju. W tej myśli też uproszono znanego artystę malarza Władysława Jarockiego, aby wprost $z$ Wenecji, gdzie urzadzał pawilon polski na światowej wystawie sztuki, udał się do Kwidzyna dla komponowania artystycznego plakatu, który rozlepiony $w$ całej Polsce, będzie dla wszystkich optycznem, a więc najbardziej narzucającem się memento $w$ sprawie plebiscytów na pótnocy $y^{38}$.

Władysław Kozicki, publikując swój tekst w dwóch częściach, określił przy tytule datę powstania tekstu na 12 i 15 czerwca oraz ze wskazaniem miejsca jego powstania - Górki koło Kwidzyna ${ }^{39}$.

Póki co nie ma żadnych innych źródeł, opisujących wizytę Jana Kasprowicza, Stefana Żeromskiego i Władysława Kozickiego na Powiślu. Żeromski wyjechał z Kwidzyna 2 czerwca, Kasprowicz i Kozicki 3 czerwca, by za kilka dni powrócić. Nie znamy daty, wiemy, że 12 czerwca przebywali w Górkach, bo taką datę nosi artykuł W. Kozickiego opublikowany w „Gazecie Warszawskiej”. 16 czerwca goście opuszczają tereny plebiscytowe.

Podczas wizyty na Powiślu Stefan Żeromski, Jan Kasprowicz i Władysław Kozicki starali się rozpoznać sytuację, poznać ludzi prowadzących kampanię przedplebiscytową, członków Międzysojuszniczej Komisji Plebiscytowej, mającej

${ }^{37}$ Szkic znajduje się w prywatnych rękach, był m.in. prezentowany na wystawie „O Niepodległą Polskę. Plebiscyt 1920 roku na Powiślu", zorganizowanej przez Muzeum Zamkowe w Malborku w oddziale muzeum Zamku w Kwidzynie w okresie 3.09-29.11.2020 r.

38 W. Kozicki, O swobodny oddech Polski, Spostrzeżenia z pótnocnych terenów plebiscytowych, cz. I, „Gazeta Warszawska", nr 167, 21 VI 1920, s. 1.

${ }_{39}$ Ibidem; W. Kozicki, O swobodny oddech Polski, Spostrzeżenia z pótnocnych terenów plebiscytowych, cz. II, „Gazeta Warszawska”, nr 169, 23 VI 1920, s. 1. 
przeprowadzić i nadzorować plebiscyt. Wszystko po to, aby po powrocie do kraju zapoznać opinię publiczną z sytuacją na terenach objętych plebiscytem. W ten sposób misja Stefana Dąbrowskiego poprzez nagłośnienie kwestii plebiscytowej w kraju została zrealizowana. Literaci, wkrótce po zakończeniu misji, jeszcze w czerwcu wydali odezwę wzywającą społeczeństwo do obrony polskości ziem położonych w Prusach Wschodnich. Odezwa ta została wręczona marszałkowi sejmu RP oraz wydrukowana w prasie ogólnopolskiej, w różnych tytułach prasowych ${ }^{40}$. Czasem z krótką adnotacją: „Kwidzyn, czerwiec 1920” lub „pod Kwidzyniem, w czerwcu 1920”. Odezwa w „Gazecie Warszawskiej” ukazała się w sąsiedztwie artykułu Władysława Kozickiego opisującego plebiscyt na nieco szerszym tle politycznym. Choć, co ciekawe - artykuł Kozickiego ukazał się na pierwszej stronie, zaś sama odezwa na drugiej ${ }^{41}$. Ciekawego spostrzeżenia dokonuje z kolei A. Z. Kłodziński, który twierdzi, że zasługą wizyty literatów na Powiślu jest z kolei przyjazd na tereny plebiscytowe już kilka tygodni później Nuncjusza Apostolskiego w Polsce Achille Rattiego ${ }^{42}$.

Trwałym śladem pobytu literatów na Powiślu jest Inter Arma - między wojna$m i$ - opis misji sporządzony przez Stefana Żeromskiego i wydany drukiem jeszcze w tym samym - 1920 r. i dziesięć lat później wznowione. Obie książeczki wydane zostały nakładem tego samego wydawnictwa, w którym Żeromski publikował wszystkie swoje prace: Wydawnictwie Jakuba Mortkowicza w Warszawie, prywatnie przyjaciela autora. Dzieło niewielkie, będące swego rodzaju zapisem pamiętnikarskim, sporządzonym nierównomiernie, w którym uwagę przykuwa raczej próba oceny miejscowego społeczeństwa pod kątem poszukiwania wątków polskości niż analiza polityczna sytuacji w Prusach Wschodnich. Czytając relacje Żeromskiego w Inter Armie i Kasprowicza w wywiadzie w „Gazecie Warszawskiej” można odnieść wrażenie, że uwagę obu autorów zajmowały te same sprawy. Kiedy Kasprowicz pisał:

...przystosowuja się do nowych warunków, ot np. hotel, w którym zatrzymaliśmy się („Königlicher Hof”) stanowit przed kilku miesiacami siedzibę hakatystów. Dziś nie słyszy się tam języka niemieckiego, choć właścicielem Niemiec. Stużba hotelowa stara się mówić po polsku. W sali restauracyjnej menu jest tylko polskie...

40 Ratujmy ziemie nadwiślańskie! Ratujmy Polskę!, „Gazeta Warszawska”, R. 140, nr 169, s. 2; Ratujmy Ziemie Nadwiślańskie, "Wiarus”, R. III, nr 26, 28 VI 1920, s. 421-422; ale także odezwę w nieco różniących się między sobą wersjach i pod różnymi tytułami publikowały m.in. „Dziennik Ludowy”; „Gazeta Lwowska”, „Kurier Lwowski”, „Słowo Polskie".

${ }^{41}$ W. Kozicki, O swobodny oddech Polski..., cz. I.

42 A.Z. Kłodziński, Żeromski i Kasprowicz w czasie plebiscytu na Warmii i Mazurach w 1920 roku, Teka Pomorska, 1938, 3, s. 99-100. 
u Żeromskiego uwagę zwraca:

...w dużym hotelu, który tam jeszcze niedawno byt siedliskiem dyktatorów minionej wojny [...] dziś służba mówi poprawna polszczyzną, a menu restauracyjne układane jest tylko po polsku...

Nawet oceny tych samych osób bywają podobne, gdy Kasprowicz pisał:

z kolei skierowaliśmy swe kroki do przewodniczącego aljanckiej komisji plebiscytowej p. Pavii. Zaręczał nam w czasie niemal 2-godzinnej rozmowy, prowadzonej z niesłychanym temperamentem, że jest jak najsympatyczniej usposobiony dla narodu polskiego.

\section{Żeromski oceniał:}

Zaraz $w$ dniu następnym złożyliśmy wizyte prezesowi komisyi koalicyjnej, panu Pavii. Wymowny włoski polityk i prawnik $w$ ciagu dobrych paru godzin przedstawiał nam historje miejscowych zatargów, udowadniając wszystko dokumentami, a wciąż zapewniając nas o swej nadzwyczajnej, niewzruszonej sympatyi dla Polski ${ }^{43}$.

Nieco inne spojrzenie przekazał swoim czytelnikom Władysław Kozicki dokonując szerszej analizy sytuacji na tle innych wydarzeń europejskich ${ }^{44}$. Wszyscy trzej zgodnie jednak stwierdzili, że wygrana w głosowaniu plebiscytowym w lipcu 1920 r. jest bardzo dużym wyzwaniem, a nawet jest trudna do osiągnięcia. Niestety, także misja „ludzi kultury” na ziemie plebiscytowe ostatecznie nie przełożyła się, nawet w najmniejszym stopniu, na ostateczny wynik głosowania, który dla Polski stał się bolesną porażką. 


\section{Odezwa Jana Kasprowicza, Stefana Żeromskiego i Władysława Kozickiego}

Źródło: „Gazeta Warszawska”, nr 169 z dnia 23 czerwca 1920 r., s. 1. Pisownia oryginalna

Ratujmy ziemie nadwiślańskie! Ratujmy Polskę!

\section{Rodacy!}

Odzywamy się do was z prastarych dzielnic naszych, z prawobrzeżnych powiatów nadwiślańskich, oraz z Warmji i t. zw. Mazowsza pruskiego. Dzielnice te, skażone napływowym żywiołem niemieckim, w przeważnej jednak części zamieszkałe przez ludność rdzennie polską, poddano nienaturalnym warunkom plebiscytowym, zamiast, iżby je z góry naszemu przysądzić państwu.

Stała się krzywda ludowi, którego setki tysięcy, niemczone od stuleci, siłą wprost zwierzęcą zamieniane w niewolniki obcego przybysza i zbójeckiego wydziercy, zachowały nie tylko język polski, ale, naogół, i duszę polską.

Dusza ta, $\mathrm{w}$ niejednym jeszcze może i uśpiona, $\mathrm{z}$ coraz to większą budzi się potęgą; w niejednym też miejscu, na niejednym wiecu, obok przejmujących skarg na ucisk i niesłychaną wprost niesprawiedliwość, której, mimo klęsk wojennych, dopuszcza się nieposkromiona buta pruska, słyszeliśmy gromkie, żelazną otuchę budzące hasło: „Chcemy i musimy należeć do Polski, bo tylko ona jest naszą jedyną prawdziwą Ojczyzną!”

Ale czyż nadzieja, zamknięta w tym wolę zwycięstwa zawierającym okrzyku serdecznym, błogosławionem, świętem stanie się ciałem, jeżeli ci do walki przedziwnym cudem zrywający się szermierze nie będą mogli równie potężnym zawołać głosem: „Pewni jesteśmy tryumfu, bo za nami cały stoi naród!?”

Niestety - z bólem to przyznać trzeba - naród ten, niewątpliwie głęboko czujący potrzebę wiekuistego utrwalenia bytu Rzeczypospolitej, nie zawsze należytą zdaje sobie sprawę już nie z obowiązku ratowania ludu polskiego, który widząc, że go w tak rozstrzygającej opuszczono chwili, że zawiedziono jego nadzieje, że podcięto jego wiarę, że nie zrozumiano jego miłości, z jaką zwraca się do najdroższej Macierzy swej, mimo, że wróg przez lat dziesiątki i setki starał się ją uczynić im obcą, strasznemu dla nas podda się losowi: niestety, naród ten zdaje się przedewszystkiem niedostatecznie rozumieć doniosłość posiadania tych dzielnic, dla życia Polski wprost niezbędnych.

Przekonujemy się, że państwo nowożyte niema warunków trwania, jeżeli na wyłączną nie posiada własność odpowiedniego dla swych obszarów wybrzeża morskiego. 
O opanowanie mórz toczyły się, toczą i toczyć się będą zapasy najkrwawsze. Naturalnem naszem i to jedynem korytem, wiodącem warunki życia, tchnienia nasze, ku szerokiemu światu, który ogarnąć można najważniejszą ze wszystkich sił, t. j. morzem, a bez którego, bez tego szerokiego świata, życie przestaje być życiem, jest matka rzek naszych, Wisła.

Jedynem naturalnem znowu środowiskiem, skupiającem wszystkie te żywotne tchnienia nasze, aby je rozprzestrzeniać falami po okręgach, iżby nietylko o naszem świadczyły życiu, ale i do nieśmiertelnego życia państwowego świeżych nabierały nasyceń, jest Gdańsk.

Gdańska nie przyznano nam bezwzględnie. Wrogowie nasi wiedzieli, i wiedzą, co czynią. Pod maską sprawiedliwości chcieli i chcą nas skrzywdzić. Ale my krzywdy znieść nie możemy. Gdańsk musi być naszym - pod formą tą czy też inną. Gdańsk przecież nie będzie naszym, jeżeli bezwzględnie naszą nie będzie Wisła. A Wisła nie będzie naszą, jeżeli nie postaramy się o to, iżby straciła charakter śmiesznego wąskiem przybrzeżem ograniczonego korytarza. Czyż można sobie wyobrazić, iżby ten przedni, najprzedniejszy, bo z posiadaniem morza związany warunek życia naszego, ta materjalnie i duchowo z ciałem i duszą związana Wisła, której lewy brzeg jest naszym, odcięta była, na swoim brzegu prawym, od naturalnego podłoża swego, od Polski? Nie! Kto tego nie uzna, ten jest albo lekkomyślny, albo - powiedzmy to otwarcie - wszelkiego politycznego pozbawiony rozumu.

Czyż jest ktokolwiek na świecie, posiadający zdolność logicznego myślenia, któryby przypuszczał, że istnieć może państwo, mające niemal w obrębie swoim dzielnice, podległe panowaniu śmiertelnego wroga naszego? Nie!

\section{Rodacy!}

Wspaniali skądinąd królowie nasi z rodu Jagiełły popełnili błąd, którego skutki czujemy przedewszystkiem dzisiaj. Przodek ich zdeptał, zdawało się, nazawsze w wiekopomnej bitwie pod Grunwaldem głowę żmiji krzyżackiej. Nie opatrzyli się jego następcy. Godząc się na hołdy, składane im przez Albrechtów, zamiast, co było w ich mocy, Albrechtów tych zmiażdżyć, stworzyli wbrew swojej woli, zarzewie, które dzisiaj, w chwili spotęgowania się poczucia narodowego, wielkim wybucha płomieniem. Sprawa ogarnięcia tego płomienia stanie się naszem życiem albo naszą - śmiercią.

Brońmy Polski Piastowskiej! Brońmy granic zachodnich! Śląsk potrzebny nam jest dla ciała, Pomeranja dla duszy, bez której ciało więdnie i zamiera. Poniechanie tej obrony, choćby najmniejsze uszczuplenie tych granic oznacza otwarcie bram tak wielkich, tak szerokich, jak te granice, bram, któremi nie przesączać, ale przewalać się będzie zalew, mający prędzej czy później pochłonąć nas na zawsze. 
Rodacy!

Zapytacie się może, któż to przemawia w ten sposób? My, tak samo jak wy, obywatele polscy. Każdy obywatel polski ma nietylko prawo, ale i obowiązek zabierać głos w chwili, kiedy najukochańszej Rzeczypospolitej śmiertelne grozi niebezpieczeństwo.

Do tego prawa i do tego obowiązku poczuwamy się my, pisarze polscy tembardziej, że tu, na tych terenach plebiscytowych, dano nam sposobność możność przekonania się, że tylko tak a nie inaczej do braci swoich odzywać się należy.

Ratujmy ziemie nadwiślańskie! Pamiętajmy o nich dziś i nazawsze bez względu na to, jak wyniknie dla nas niesprawiedliwy ten plebiscyt.

Jan Kasprowicz Władysław Kozicki

Stefan Żeromski

Kwidzyń, w czerwcu 1920r.

\author{
Szanse plebiscytowe \\ Wywiad z Janem Kasprowiczem
}

„Gazeta Warszawska”, nr 153 z dnia 7 czerwca 1920 r., cz. I, s. 1. Pisownia oryginalna

I

Największy poeta Polski współczesnej, prof. Uniwersytetu Lwowskiego dr. Jan Kasprowicz wraz ze świetnym pisarzem Stefanem Żeromskimi i wybitnym krytykiem artystycznym dr. Władysławem Kozickim udali się z polecenia ministerjum spraw zagranicznych na północny teren plebiscytowy.

Niedaleką jest chwila, w której Warmja i Mazury zadecydują o swym dalszym losie politycznym. To też Polska coraz częściej kieruje swój wzrok ku granicom północnym i coraz uważniej wsłuchuje się w odgłos wydarzeń przedplebiscytowych.

Korzystając z kilkudniowego pobytu Jana Kasprowicza w Warszawie, prosiliśmy go, aby podzielił się z nami swemi wrażeniami i przeżyciami na terenach północnych. Prośbie naszej stało się zadość.

- Wyjechaliśmy - mówił Jan Kasprowicz przed 3 tygodniami. Wyjechaliśmy tem chętniej, żeśmy sobie zdawali sprawę z doniosłości tych terenów plebiscytowych dla Polski. 
Zatrzymaliśmy się na krótko w Grudziądzu. Ogarnęło nas zdziwienie, jak szybko Grudziądz, to ognisko hakatyzmu, nabiera cech polskich. Przecież to zaledwie przed kilku miesiącami Grudziądz zjednoczył się z Polską, a już na każdym kroku uderza jego polska fizjonomja: szyldy przemalowane na polskie, na ulicy słyszy się co i rusz język polski. Zaczepialiśmy przechodniów: przeważnie natrafialiśmy Polaków.

- A cóż Niemcy?

- Przystosowują się do nowych warunków ot np. hotel, w którym zatrzymaliśmy się („Königlicher Hof”) stanowił przed kilku miesiącami siedzibę hakatystów. Dziś nie słyszy się tam języka niemieckiego, choć właścicielem Niemiec. Służba hotelowa stara się mówić po polsku. W sali restauracyjnej menu jest tylko polskie.

Polskość Grudziądza zamanifestowała się wspaniale przed kilku dniami, gdyśmy wracali do Warszawy. Był dzień Bożego Ciała. Po raz pierwszy od rozbiorów Polski na ulice miasta wyszła procesja. Uczestniczyły w niej tłumy wiernych i wojsko. Olbrzymia, wspaniała procesja wywarła niesłychane wrażenie.

- Jakie punkty ziem plebiscytowych zwiedzili panowie?

- Przedewszystkiem - Kwidzyń. Zatrzymaliśmy się w hotelu „Cassino”, niedawno niemieckim, obecnie zakupionym przez Polski Komitet Plebiscytowy.

Kilka dni później zaprosił nas do swojego majątku Górki p. Jan Kowalski, obywatel ziemski, pochodzący z Kujaw, który przed 10 laty nabył piękne Górki od Niemca. Obecnie sprawuje odpowiedzialne funkcje starosty Kwidzyńskiego z polskiej strony.

$\mathrm{W}$ jego gościnnym dworze mieliśmy „pied a terre”.

- I zapewne rozpoczęli pp. szereg wycieczek?

- Pierwszym krokiem naszym było złożenie wizyty konsulowi polskiemu w Kwidzynie p. Sierakowskiemu z Waplewa, pow. Malborskiego.

- Byli pp. zapewne u p. Pavii?

- Istotnie, z kolei skierowaliśmy swe kroki do przewodniczącego aljanckiej komisji plebiscytowej p. Pavii. Zaręczał nam w czasie niemal 2-godzinnej rozmowy, prowadzonej z niesłychanym temperamentem, że jest jaknajsympatyczniej usposobiony dla narodu polskiego. Te zaręczenia wydały mu się snać potrzebne, bo trafiliśmy na chwilę, gdy w sferach polskich ogromne było wrzenie z powodu krwawych zajść na wiecu i podczas pochodu w Kwidzynie.

Mówiono nam, że p. Pavia niedość energicznie zajął się sprawą. Podwładne mu wojsko włoskie spełniło, jakkolwiek nieco za późno - według zapewnień z polskiej strony - swój obowiązek.

Stosunki między społeczeństwem polskiem a p. Pavią zaostrzył list p. Pavii, wystosowany w tonie ojcowskim do Rady Ludowej Polskiej, żądający zachowania spokoju it.d. 
Przewodniczący Polskiej Rady Ludowej w Kwidzynie odpowiedział listem bardzo ostrym.

Stanowisko p. Pavii wywołuje wiele zastrzeżeń wśród Polaków.

- Jakie są szanse nasze w Kwidzynie?

- Byliśmy tam na wiecu ludowym, naprędce dla nas zwołanym. Przekonaliśmy się, że i w tem niemieckiem mieście znajduje się ludność polska. Są to przeważnie robotnicy. Obok nich niewielka liczba urzędników państwowych niemieckich, którzy nie czując już nad sobą knuta niemieckiego, przyznają się do polskości.

Ludzie ci boją się przecież o swą przyszłość w razie przegranej polskiej. Wyrazem tych obaw były zapytania prywatne, czy w razie powrotu rządów niemieckich Polska by się nimi zajęła.

Odpowiedziałem i zaręczyłem, że tak, bo Polska urzędników potrzebuje.

- A poza Kwidzyniem? Zwiedzali pp. inne powiaty?

- Byliśmy w Sztumie. Trafiliśmy na pochód i zabawę powiatowego Koła Rolniczego, którego prezesem jest p. Donimirski z Hohendorfu (zapomn. nazwa „Czermień"). Pochód nas bardzo zaciekawił. Widzieliśmy same powozy - z muzyką na czele - konwojowane przez jeźdźców na doskonałych koniach. Zdawało nam się, że to jest tamtejsze obywatelstwo ziemskie. Tymczasem, ku naszemu zdziwieniu, przekonaliśmy się, że to nie żadna szlachta, jeno bogaci chłopi.

Sama zabawa składała się z tańców i przedstawienia dramatycznego, odegranego przez córki gospodarzy.

Zainteresował nas język. Trzeba niestety powiedzieć sobie, że język polski uległ tutaj w znacznym stopniu wpływom niemieckim. Nie tylko pod względem zwrotów, ale i strona dźwiękowa języka razi przybysza z innych stron Polski.

Tembardziej chwytało nas za serce głębokie poczucie polskości.

- Widoki plebiscytu?

- W pow. Sztumskim, a przynajmniej w pewnych jego częściach wypaść mogą korzystnie. Tak nas zapewniało kilku obywateli, z którymi mieliśmy sposobność rozmawiać.

- Czego możemy się spodziewać w innych powiatach?

- Znacznie gorzej wygląda sytuacja w powiatach Suskim, Malborskimi Kwidzyńskim. Tam - większość zniemczona lub niemiecka. Byliśmy np. w Prabutach. $\mathrm{Z}$ rozmowy $\mathrm{z}$ ks. proboszczem dowiedzieliśmy się, że parafia liczy zaledwie 200 Polaków, niezbyt uświadomionych.

- Czy jednak intensywna akcja z polskiej strony nie poprawiłaby sytuacji?

- Akcję się prowadzi. Lecz robota w tych wszystkich powiatach jest tem trudniejsza, że prócz rządu - przeszkadzają silnie księża, niejednokrotnie polskiego pochodzenia, lecz należący do centrum. 
Księża ci, jak np. między innymi ks. Rosentreter, prob. w Gniewie, brat biskupa chełmińskiego, prowadzą na terenach, które już weszły w skład Polski, swą akcję germanizatorską.

- Dlaczego nie pomyślano o kontrakcji?

- Owszem, zastanawiano się nad tem.

Ponieważ jednak na biskupa liczyć nie można, powstała myśl udania się do Nuncjusza Rattiego o pomoc.

Jakie owoce krok ten przyniesie - nie wiadomo. Obowiązkiem rządu naszego jest zająć się tą sprawą. Nuncjusz Ratti powinien interwenjować ze stanowiska interesu kościoła, gdyż postępowanie księży germanizatorów wytwarza wśród ludności szczerze polskiej ferment, mogący się odbić - jak nas zresztą informowano - na samym katolicyzmie.

M.T.

\author{
Szanse plebiscytowe \\ Wywiad z Janem Kasprowiczem
}

„Gazeta Warszawska”, nr 154 z dnia 8 czerwca 1920 r. cz. II, s. 2. Pisownia oryginalna

(Dokończenie)

- W Gniewie - informował dalej J. Kasprowicz - znaleźliśmy gościnę u miejscowego starosty p. Czarnowskiego. Bardzo dzielny obywatel. Nie mając wyszkolonych urzędników polskich, zdobył się przecież na krok stanowczy, funkcjonariuszy niemieckich usunął i w krótkim stosunkowo czasie zorganizował należycie swoją działalność.

- Byliśmy w Malborgu. Zwiedzaliśmy zamek. W bramie zamku natknęliśmy się na grupkę ludzi z orzełkami na czapkach. „Polacy jesteście” - padło pytanie. „A naturalnie, jesteśmy ze Tczewa”.

- Jakie wrażenie robi Malborg?

- Miasto - niemieckie. Mówiono nam jednak, że i Niemcy malborscy przystosowaliby się w razie wygranej polskiej do nowych warunków. Naturalnie ze względów praktycznych.

Tak samo w Kwidzynie. Jeszcze przed kilku tygodniami kupcy tamtejsi uczyli się gwałtownie języka polskiego.

Niestety. Niepewne postępowanie komisji aljanckiej rozzuchwala szowinistyczne żywioły niemieckie, a u ogółu - zanika poczucie potrzeby przystosowania się. 
Niemcy coraz bardziej podnoszą głowy. Na wiecu w Kwidzynie skarżyły się ze łzami w oczach kobiety polskie, że nie można na ulicy mówić po polsku, ażeby się nie spotkać z pogróżkami i wyzwiskami w rodzaju „verfluchte Polaken”. Obok pogróżek w Kwidzynie planowano nawet zamachy. W kołach agitatorskich niemieckich naznaczono od 1 do 2 tys. marek za głowę działacza polskiego.

- Cóż robi komisja aljancka? Dlaczego nie troszczy się o bezpieczeństwo Polaków, o swobodę akcji plebiscytowej?

- W ostatnich dniach poczyniła nareszcie pewne kroki. Po naszej wizycie u p. Pavii, gdzieśmy również poznali szczerze nam oddanego przedstawiciela Francji hr. Cherisay i niezbyt dla nas życzliwego reprezentanta Anglji p. Beaumonta, komisja zdecydowała się wysyłać na wiece polskie odpowiednią ilość żołnierzy.

Tak się stało $\mathrm{z}$ wiecem $\mathrm{w}$ Iławie, na którym - niestety - nie mogliśmy być. Wysłany po nas samochód - podobno w drodze się zepsuł, a jak nam mówiono naumyślnie nie dotarł do nas, gdyż szofer był Niemcem.

Tak samo pod osłoną wojska włoskiego odbyło się przed tygodniem zgromadzenie robotników w Kwidzynie oraz więc w Gardei, na drodze do Grudziądza. $\mathrm{Na}$ tym wiecu przemawiał b. gorący patrjota polski, urodzony na Warmji i po niemiecku wychowany ks. dr. Rudolf Nowowiejski, brat znanego muzyka - Feliksa Nowowiejskiego.

- Zwiedzali pp. powiat Suski. Jakiż obraz?

- Byliśmy w Prabutach, jak już wspominałem, oraz w Iławie. Pytaliśmy, jak się zachowują wobec dążeń naszych już nie junkrzy, lecz socjaliści. Odpowiedziano nam ze strony polskiej i to ze strony sprzyjającej ideom socjalistycznym, że postępowanie socjalistów jest jednoznacznem ze stanowiskiem nacjonalistów. Ta sama nienawiść.

Powiat Suski zresztą - to gniazdo junkrów. Pomiędzy nimi jest wielu przyjaciół osobistych Wilhelma, jak hr. Oldenburg, hr. Brunneck, hr. Dohna-Schlobitten, hr. Dohna-Finkenstein i in. Powiat ten stanowi najżywsze ognisko ruchu monarchistycznego niemieckiego.

$\mathrm{Z}$ tych stron pochodzi przecież i Kapp.

- Co się dzieję w pow. Olsztyńskim?

- Byliśmy i tam. Komitet polski, wskutek znanego pobicia trupy polskiej w Biskupcu, które mogło się skończyć śmiercią kilku ludzi i wskutek niezwykłych trudności zatrzymał swe prace. Obecnie przyszedł do przekonania, może i pod naciskiem rządu, że prace te przecież podjąć należy na nowo. I podjęto ją. Idzie $\mathrm{z}$ uporem.

Według słusznego zdania członków tamtejszego komitetu najlepszymi krzewicielami polskości byliby - między innymi - nauczyciele. W pow. Olsztyńskim 
założono kilkadziesiąt szkół polskich. Zażądano 70 sił nauczycielskich. Jak dotąd - otrzymano zaledwie 3-4. Trudność polega na tem, że nauczycielami na Warmji mogą być tylko nauczyciele wykształceni w seminarjach niemieckich.

Zgłosiła się - co prawda pewna liczba nauczycieli z Poznańskiego, niebawem jednak cofnęli się mimo b. korzystne warunki materjalne. Prawdopodobnie z obawy o bezpieczeństwo osobiste.

Niemcy chwycili się w pow. olsztyńskim zresztą i w innych powiatach plebiscytowych, bardzo dotkliwego środka: banki niemieckie wypowiadają hipotekę nie tylko większym właścicielom, lecz i mniejszym gospodarzom. Pewna część niewątpliwie cios ten wytrzyma. Ale mniejszym gospodarzom grozi to naogół zupełną ruiną.

Oglądają się ci ludzie na Polskę, spodziewając się od niej pomocy.

- Pomoc ta - podkreślił z naciskiem Jan Kasprowicz -wjakiejkolwiekbądź formie jest niezbędna. Ubytek tych uświadomionych gospodarzy Polaków może b. niekorzystnie wpłynąć na plebiscyt.

- Czy w pow. olsztyńskim możemy liczyć na powodzenie?

- Powiat Olsztyński uważany jest w pewnej przynajmniej części za wygrany.

W samym Olsztynie trafiliśmy na zebranie tamtejszego Tow. Ludowego. Przemawiał prezes Komit. plebiscyt. w Kwidzynie i na Warmji ks. pos. Ludwiczak. Działalność jego ogromnie jest owocna. Przemawiałem i ja. I przekonałem się, jak lud tam łaknie szczerze polskiego słowa.

- A na Mazurach?

- Nie znam jeszcze Mazurów. Mamy zamiar obecnie zwiedzić ten piękny kraj. Słyszeliśmy jednak, że ewangelicki lud nasz uległ silnie germanizacji, prowadzonej intensywnie przez rząd i większość duchowieństwa. Nie tylko pastorowie ludowego pochodzenia, zgermanizowani przez szkołę, nie mający już tradycji polskiej, ale i o nazwiskach szlacheckich nie tylko zapomnieli o swem pochodzeniu, ale aby pamięć o tem pochodzeniu zatrzeć agitują w sposób wprost wściekły przeciwko Polsce.

Taki pastor Pomian Abramowski zapełnia pisemko swoje najordynarniejszymi wyzwiskami na Polaków.

A jednak gdyby plebiscyt odbył się 1 i pół r. lub 2 później, znaczną część ludu mazurskiego możnaby pozyskać dla Polski. Po latach 20 lud ten przekształciłby się na żarliwych polskich obywateli.

- I cokolwiek będzie - rzekł z mocą Kasprowicz - 400 tys. ludu ewangelickiego na Mazurach, demoralizowanego przez rząd niemiecki i pastorów, musi wrócić do Polski.

- Jednakże całość obrazu na terenach plebiscytowych - zauważyłem - nie wygląda zbyt różowo. Jakie pan widzi drogi i środki? 
- Miarodajne czynniki polskie obowiązane są wszelkiemi siłami dążyć, jeśli idzie o dzisiejszą, bezpośrednią chwilę do odsunięcia terminu plebiscytu.

Całe społeczeństwo polskie powinno gorąco się przejąć sprawą tych spornych dzisiaj terenów nadwiślańskich. Sprawa ta - powiedzmy to sobie otwarcie wiąże się jaknajściślej z kwestją istnienia Polski.

Nie uzyskawszy tych terenów - nie możemy liczyć na posiadanie Gdańska. Posiadanie Gdańska jest - zdaniem i naszem i tamtejszej ludności, i tych kół aljanckich, które nam są szczerze życzliwe - ściśle związane z posiadaniem tych spornych dziś terenów.

Zaś bez Gdańska i morza - byt państwa polskiego jest zagrożony.

M.T.

\author{
WŁADYSŁAW KOZICKI \\ O swobodny oddech Polski, Spostrzeżenia z północnych \\ terenów plebiscytowych,
}

„Gazeta Warszawska”, cz. I, nr 167 z dnia 21 czerwca 1920 r., s. 1. Pisownia oryginalna

Górki pod Kwidzynem, 12 czerwca

Stara to prawda, że myśli najczystsze, idee najwznioślejsze stawały się niejednokrotnie $\mathrm{w}$ toku dziejów najbardziej wyrafinowanem narzędziem tortury ludzkości. Prezydent Wilson ideolog i teoretyk, niemający dość silnego poczucia rzeczywistości, działał niewątpliwie w najlepszej wierze, gdy kładąc na szalę całą wagę i powagę Stanów Zjednoczonych, wysunął tezę swobodnego stanowienia narodów o sobie. Lecz chytrzy, sprytni i nieznający skrupułów europejscy mężowie stanu w lot połapali się, że z tej mąki absolutnej sprawiedliwości można upiec doskonale chleb bardzo pospolitego interesu i wymyślili plebiscyty, ów piekielny środek przedłużenia wojny światowej. W ten sposób rycerską tarczę wolności, którą świat chciał osłonić amerykański idealista - przekuto na egoistyczną broń polityczną, mającą służyć przedeszystkiem interesom Anglji i Włoch, a zarazem przynieść bezpośrednią korzyść Niemcom.

Ile krzywdy ludzkiej sprowadziły, ile łez i krwi polskiej wytoczyły już dotychczas plebiscyty na obu Śląskach, na Spiżu i na Orawie, o tem opinja polska 
dokładnie jest poinformowana, bo sprawą tą od początku stale i szczegółowo zajmowała się zarówno prasa, jak Sejm i rząd. Natomiast - stwierdzić to trzeba z żalem - mało kto w Polsce zdaje sobie sprawę, jak niesłychanie ważne znaczenie dla przyszłości Rzeczypospolitej i dla jej mocarstwowego rozwoju mają północne tereny plebiscytowe. Prasa nasza tylko dorywczo i przypadkowo poświęcała tej kwestji nieliczne artykuły, w Sejmie nie mówiono o niej prawie zupełnie, a także rząd przez dłuższy czas niewiele robił, aby społeczeństwo uświadomić w tym kierunku.

Zmiana korzystna nastąpiła dopiero od czasu objęcia przez dr. Stefana Dąbrowskiego teki podsekretarza stanu w Ministejum spraw zagranicznych. Bystry i przewidujący ten polityk zrozumiał odrazu doniosłość problemu i ułożył cały plan akcji, zmierzającej do rozgrzania ogółu polskiego i zapalenia go do sprawy plebiscytów na północy. Jednym z szczegółów tego programu było zainteresowanie zagadnieniem warmińskiem i mazurskiem sfer artystycznych i literackich, aby przez zaprzągnięcie do służby dla tych ziem suggestywnej mocy sztuki, związać ściśle losy tego kraju z sercami i uczuciami polskiemi. W wykonaniu tego planu prezydent rady ministrów zwrócił się z inicjatywy dr. Dąbrowskiego do Jana Kasprowicza, Stefana Żeromskiego i podpisanego z zaproszeniem do odbycia podróży po północnych terenach plebiscytowych, celem naocznego poznania tych obszarów, wyczucia nastrojów miejscowych i podzielenia się odniesionemi wrażeniami z Polakami w kraju. W tej myśli też uproszono znanego artystę malarza Władysława Jarockiego, aby wprost z Wenecji, gdzie urządzał pawilon polski na światowej wystawie sztuki, udał się do Kwidzyna dla komponowania artystycznego plakatu, który rozlepiony w całej Polsce, będzie dla wszystkich optycznem, a więc najbardziej narzucającem się memento w sprawie plebiscytów na północy.

Zanim później będę miał sposobność zakomunikowania swych wrażeń i spostrzeżeń co do narodowościowych, politycznych i ekonomicznych stosunków w tych krajach, co do jego pejzażu i właściwości tutejszego ludu polskiego, a wreszcie co do prac obu komitetów plebiscytowych: warmińskiego i mazurskiego, pragnę na razie, w tej wstępnej korespondencji podać tylko kilka najogólniejszych, a zarazem najbardziej zasadniczych uwag.

Po trzytygodniowem skrupulatnem badaniu na miejscu kwestji północnych terenów plebiscytowych, po zetknięciu się z najwybitniejszymi działaczami i politykami z tych obszarów i z polskiego Pomorza, po poznaniu Kwidzynia, Sztumu, Malborka, Prabutów, Suszu, Iławy, Ostrudzia i Olsztyna, po zaznajomieniu się z ludem i z robotnikami na wiecach i zabawach ludowych, a wreszcie po rozmowach z przedstawicielami tutejszego patrjotycznego ziemiaństwa w Waplewie, Buchwałdzie, Zajeziorem pod Sztumem i w Górkach pod Kwidzynem - doszliśmy wszyscy trzej do zgodnego a niezachwianego przekonania, że objęcie $\mathrm{w}$ trwałe posiadanie 
przez Polskę czterech powiatów, położonych po prawym brzegu Wisły, czyli tak zwanej Pomeranji, Warmji katolickiej i Mazowsza pruskiego jest poprostu kwestją bytu Rzeczypospolitej, jako państwa silnego i naprawdę niezależnego. Dopiero bowiem zdobycie tych obszarów umożliwi Polsce silne postawienie nogi w Gdańsku, a bez Gdańska i bez naprawdę wolnego dostępu do morza, bez tego swobodnego oddechu handlowego i państwowego, jaki nam tylko Bałtyk dać może, Polska będzie skazana na śmierć przez powolne uduszenie. Pomeranji Polska wyrzec się nie może, bo przez nią prowadzą dwie linje kolejowe, mające pierwszorzędne znaczenie pod względem ekonomicznym, przedewszystkiem zaś strategicznym, a mianowicie najkrótsze połączenie Warszawy z Gdańskiem przez Mławę, Iławę, Susz, Malbork i najkrótsze połączenie Torunia z Gdańskiem przez Chełmżę, Grudziądz, Kwidzyń, Sztum i Malbork. Warmji zaś i Mazurów Polska wyrzec się nie może nietylko dlatego, że na obszarach tych mieszka na ogólną liczbę ludności, wynoszącej 591.000 głów, mieszkańców mówiących po polsku 436.000, którzy wprawdzie narazie uważają się w znacznej części za Niemców, otumanieni przez wiekowy ucisk polityki germanizatorskiej, lecz nad którymi trzeba najwyżej przez dwadzieścia lat oświatowo i narodowo popracować, aby głęboko na dnie ich dusz drzemiące poczucie polskości wspaniałym zalśniło blaskiem, lecz przedewszystkiem dlatego, że posiadanie tych ziem jest niezbędnie potrzebne dla obrony granic Rzeczypospolitej, dla zabezpieczenia stolicy państwa, odległej zaledwie o trzy dni marszu od Mazowsza pruskiego, dla wyrzucenia z naszego organizmu tej brutalnej siekiery, jaką wbito w grzbiet Polski w postaci Prus wschodnich przyłączonych do Niemiec. Pomijam już to, że wszystkie północne tereny plebiscytowe mają tak wysoką kulturę rolną po wsiach i handlową po miastach, iż jeden kilometr kwadratowy ziemi tutaj wart jest więcej, niż setki kilometrów „sprzymierzonego” obszaru gdzieś na Białorusi lub Ukrainie.

Wskutek oszczędzającej Niemcy polityki Lloyda George’a i sekundujących mu premjerów włoskich, północne kresy Polski i przylegające do nich pobrzeże bałtyckie otrzymały konfigurację pod względem politycznym i strategicznym tak absurdalną, że na dłuższą metę żadną miarą nie da się jej utrzymać. Korytarz, łączący Polskę z morzem, miejscami tak wąski, że pociski armat niemieckich z obu stron $\mathrm{z}$ łatwością objąć go mogą, amfibijny pokurcz polityczny, jakim jest wolne miasto Gdańsk - to są nonsensy, które w niedługim czasie Niemcy albo Polska usuną z powierzchni świata. Niemcy dziś są jeszcze bezsilne i do akcji wojskowej w większym stylu niezdolne, ale podniosą się rychło, tem prędzej, że mają możnych protektorów z w Anglji i Włoszech, a wtedy pierwszym ich czynem wojennym będzie przecięcie tej cieniutkiej nitki, na której wisi polski dostęp do morza. O tem powinna Polska pamiętać i o tem także, że humbug, który nosi miano Ligi 
narodów od katastrofy tej nas nie ocali. Rząd polski powinien więc już w tej chwili $\mathrm{z}$ całą powagą postawić sobie pytanie, czy chce mieć Polskę wielkiem i naprawdę niezależnem mocarstwem, a wtedy musi zaraz, bez żadnej zwłoki, bo mamy najwyżej już tylko pięć minut czasu, wytężyć wszystkie siły, aby uzyskać rzeczywisty, a nietylko fikcyjny dostęp do morza, a więc posiąść Gdańsk, oprzeć go na silnym fundamencie Pomeranji, Warmji i Mazurów, z Prus Wschodnich zaś utworzyć oddzielne państewko niemieckie pod protektoratem Polski. Jeśli zaś jest możliwy jakiś rząd naprawdę polski, któryby tego nie chciał, niech zrezygnuje z osiągnięcia tych wszystkich celów politycznych, ale w takim razie niech wie, że tem samem skarze Polskę na żywot suchotniczy, że wyznaczy jej role bawidełka bezsilnego w ręku potęg światowych.

Czynniki, które ponoszą dziś odpowiedzialność za losy Rzeczypospolitej zdają się nie doceniać ogromnej doniosłości dostatecznego dostępu do morza i zabezpieczenia granic państwa od strony Niemiec. Zahypnotyzowane ściganiem mar federacyjnych po stepach ukraińskich, tracą z oczu kresy zachodnie, zapominając o tem wielkiem doświadczeniu historycznem, że jedną z najistotniejszych przyczyn upadku Polski było rozlanie się jej wpływów politycznych szeroką a cienką warstwą po rozległych obszarach wschodu, połączone z zaniedbaniem wybudowania potężnego wału obronnego przeciw żarłocznemu żywiołowi germańskiemu, który przed wiekami, tak samo jak dziś, groził nam zalewem.

Ze sfer oficjalnej polityki polskiej dochodzą nas zdania, że Polska dziś musi cały swój wysiłek militarny i polityczny skierować na wschód, bo tam mamy wolna rękę i możemy stworzyć taki stan rzeczy, jaki nam dogadza, podczas gdy na zachodzie jesteśmy skrępowani i musimy zadowolić się tem, co nam koalicja łaskawie przyznać raczy. Nic fałszywszego! Przedewszystkiem wiadomo każdemu, że koalicji oddawna niema, że jest tylko Francja, która we własnym interesie stale i wiernie sekunduje nam w grze politycznej i Anglja, która dąży do osłabienia polski, aby tą drogą nie dopuścić do nadmiernego wzrostu potęgi Francji, a wreszcie Włochy, które - jest to w świecie dyplomatycznym publiczną tajemnicą - zawarły już z Niemcami ciche przymierze, a więc pozostając $\mathrm{z}$ nimi w takim samym stosunku jak przed wojną, nie mogą iść po linji aspiracji polskich. Wobec takiej konstelacji politycznej niema dla Polski donioślejszego i żywotniejszego problemu nad problem terenów plebiscytowych i ziem dotąd tylko luźnie z Rzeczypospolitą związanych. Od pomyślnego rozwiązania tych zagadnień zależy cały byt i przyszłość Polski.

Coprawda zwolennicy obecnej oficjalnej polityki polskiej posuwają swą lekkomyślność tak daleko, iż twierdzą, jakoby Polska nie potrzebowała Gdańska, bo będzie miała, dzięki sojuszowi z Petlurą połączenie morskie ze światem przez port edeski, należący do sprzymierzonej republiki ukraińskiej. Dziecinność tego 
twierdzenia nie wymaga chyba komentarzy i osądza sama dosadnie rozum polityczny autorów tej koncepcji.

Powiadają jednak przeciwnicy nasi, że nie mamy żadnych uzasadnionych praw do Gdańska i północnych terenów plebiscytowych. Sir Reginald Tower miał się podobno wyrazić niedawno, że Polska ma takie prawa do Gdańska, jak ... Japonja! Na to należałoby mu odpowiedzieć argumentem, który z pewnością najłatwiej znajdzie przystęp do realnego i praktycznego mózgu angielskiego. Należałoby mu odpowiedzieć, że poza prawami historycznemi do Gdańska i Warmji, ekonomicznemi i strategicznemi do Pomeranji i etnograficznemi do tejże oraz do Warmji i Mazowsza pruskiego mamy do tych ziem daleko większe prawa, niż Anglja do Gdańska lub do Kłajpedy, w której mocno się usadawia, albo do Gibraltaru, w którym siedzi oddawna. Prawem tem jest najświętsze z praw zarówno dla poszczególnego człowieka jak dla całego narodu: prawo życia, prawo swobodnego oddechu. A dla realizacji tego prawa Gdańsk i północne tereny plebiscytowe są równie ważne jak Śląsk Górny Cieszyński dla ekonomicznej siły państwa polskiego.

\section{WŁADYSŁAW KOZICKI \\ O swobodny oddech Polski, Spostrzeżenia z północnych terenów plebiscytowych}

„Gazeta Warszawska”, cz. II, nr 169 z dnia 23 czerwca 1920 r., s. 1. Pisownia oryginalna

Górki pod Kwidzynem, 15 czerwca 1920

Poza głębokiem przeświadczeniem, że przyłączenie do Polski Gdańska, Pomeranji, Warmji i Mazowsza pruskiego jest nieodzownym warunkiem pomyślności i potęgo Rzeczypospolitej, drugie niezłomne przekonanie, jakie wynieśliśmy z podróży po północnych terenach plebiscytowych jest to, że plebiscyty, zarówno na obszarze olsztyńskim jak kwidzyńskim, nie są poważną, szczerą akcją, mającą umożliwić ludności swobodne wypowiadanie swej woli w sprawie przynależności państwowej, ale kosztowną i z ogromnym aparatem przygotowawczym połączoną komedją, zainscenizowaną $\mathrm{w}$ tym celu, aby pod pozorem wymiaru bezwzględnej sprawiedliwości, tem pewniej i bezpieczniej przyznać terytorja te Niemcom. Jaki ma być wynik plebiscytu, o tem już zgóry przesądzono w Paryżu i w gabinetach dyplomatycznych. Wszystko, co pozatem rozgrywa się w Kwidzynie i Olsztynie, jest tylko wielkiem widowiskiem popularnem dla ludów Europy, spragnionych zadowolenia poczucia sprawiedliwości, rodzajem commedia dell’arte, zagranej przez 
angielskich i włoskich aktorów według tekstu, ułożonego przez panów Lloyd George'a i Nittiego.

Dowodów, że tak jest, przytoczyć można niemało.

Chociaż traktat wersalski, wprawdzie nie w głównym swym akcie, ale w jednym $\mathrm{z}$ aneksów, przewiduje, że plebiscyty w obszarze kwidzyńskim i olsztyńskim powinny odbyć się $\mathrm{w}$ terminie późniejszym, aby ludność polska miała możność odetchnięcia i otrząśnięcia z wpływów wiekowego terroru niemieckiego, rada ambasadorów już w kwietniu, a więc prawie u wstępu do akcji plebiscytowej postanowiła, że głosowanie w obu obszarach północnych musi nastąpić najpóźniej w lipcu. Wszelkie usiłowania dyplomacji polskiej, aby uzyskać wydatne przedłużenie terminu plebiscytowego, wszelkie przedstawienia w tej sprawie, zarówno wobec miejscowych komisji międzysojuszniczych, jako też w Paryżu, pozostały bez skutku. Żądania Polski poparł tylko reprezentant Francji, natomiast przedstawiciele Anglji, Włoch i Japonii (ci ostatni idą zawsze za głosem Anglji) sprzeciwili się im stanowczo, opierając się na raportach Włocha, p. Angela Pavii, przewodniczącego komisji koalicyjnej w Kwidzynie i Anglika p. Renniego, przewodniczącego tejże komisji w Olsztynie. Obaj ci panowie wyrazili zapatrywanie, że akcje plebiscytowe są już dostatecznie przygotowane i że dalsze odkładanie głosowania byłoby kosztownym, bezcelowym ciężarem dla mocarstw sprzymierzonych. W rezultacie obaj prezesi komisji plebiscytowych wyznaczyli zgodnie ostateczny termin głosowania w Kwidzyńskiem i Olsztyńskiem na 11 lipca.

Oczywiście Niemcy uderzyli w wielki dzwon tryumfu, decyzja ta bowiem zapewnia im z góry zwycięstwo na całej linii.

Poza fatalnem dla interesów Polski skróceniem terminu głosowania, także cała działalność komisji międzysojuszniczych wykazuje od początku znamiona akcji wybitnie germanofilskiej. Według postanowienia traktatu wersalskiego, komisjom plebiscytowym przysługuje prawo usunięcia $\mathrm{z}$ terenu wszystkich urzędników administracyjnych, którzyby czynności swego urzędu spełniali w sposób, uwłaczający zasadzie uprawnienia obu narodowości. Otóż jest faktem notorycznym, że biurokracja niemiecka na północnych terenach plebiscytowych stała i stoi na usługach polakożerstwa i hakatyzmu. Tu bowiem właśnie jest gniazdo junkierstwa pruskiego, tu planowało się i podsycało zamachowe plany Kappa, tu, jak w powiecie pruskim, siedzą ci von Oldenburgi, Brunnecki i Dohna-Finkensteiny, którzy dziś jeszcze do spółki z byłym Kronprinzem niemieckim, knują spiski na rzecz restauracji Hohenzollernów. Mimo to, mimo szeregu jaskrawych nadużyć ani p. Pavia, anie p. Rennie nie uznali za stosowne usunąć choćby jednego urzędnika niemieckiego. $\mathrm{W}$ ostatnich dopiero tygodniach urządzono w Kwidzynie wydalenie wiceburmistrza, ale z powodów zupełnie innych, mianowicie za znieważenie 
oficera włoskiego. Namacalnym dowodem germanofilstwa i stronniczości komisji plebiscytowej jest fakt, że o usunięcie landrata sztumskiego von Anversa znanego hakatysty, któremu udowodniono mnóstwo gwałtów, popełnionych na Polakach, walczy komitet warmiński od kilku tygodni i dotąd nawet tego małego ustępstwa nie zdołał uzyskać.

Cały aparat administracyjny pozostał więc w ręku niemieckich hakatystów, których nienawiść do Polaków, agitacja pangermańska rozżarzyła do białości. Urzędnicy ci są oczywiście równocześnie najgorliwszymi i najniebezpieczniejszymi członkami propagandy niemieckiej, której oddają jak najlepsze usługi, bo rozporządzają wolnym atutem władzy i posiadaniem podatnego do wszelkich nadużyć i fałszerstw instrumentu biurokratycznego. Pod opiekuńczemi skrzydłami tej biurokracji bojówki niemieckie, rozmaite „Hauskommando” i poprzebierane po cywilnemu Grenzschutze hulają w najlepsze i urządzają krwawe awantury, które czasami dochodzą do rozmiarów istotnych pogromów. Tak było w Malborku, Biskupcu, Lecu, Kwidzyniu itd. Bojówki te udaremniały do niedawna wszelkie wiece i całą wogóle polska pracę agitacyjną, dotego stopnia, że - jak wiadomo - komitet mazurski musiał na pewien czas zupełnie zawiesić swą działalność. Czyż w tych warunkach plebiscyty nie są prostym humbugiem i czczą igraszką? Czyż równouprawnienie Polaków nie jest w takich stosunkach krwawą ironją.

Dopiero w ostatnich tygodniach przed głosowaniem, kiedy pewne ustępstwa sprawie niemieckiej nie mogły już zaszkodzić, przyznały komisje plebiscytowe ( $\mathrm{w}$ Kwidzynie przed końcem kwietnia i w maju, w Olsztynie zaś dopiero w czerwcu) przeważnie pozorne raczej, niż realne koncesje Polakom. Rozwiązano więc dawne, wyłącznie niemieckie "Sicherheitswehry” i zastąpiono je mięszanemi polsko-niemieckiemi z udziałem Polaków - jednak stanowczo nieodpowiadającym stosunkowi obu narodowości. W Olsztyńskiem zresztą, dotychczas reformy tej nie przeprowadzono, choć ją w zasadzie zadecydowano. Przyznano dalej polskich inspektorów szkolnych i przydzielono landratom polskich adjunktów (starostów) z prawem wglądu w akta urzędowe, lecz bez jedynego realnego prawa, jakiem mogłoby być tylko prawo kontrsygnowania zarządzeń landratury. Odmówiono natomiast żądaniu przydzielenia polskich przedstawicieli do boku niemieckich wiceburmistrzów, co wobec wielkiej ingerencji gmin w zakresie przygotowania plebiscytu jest wyraźnym aktem stronniczości na rzecz Niemiec. Wreszcie od czasu krwawego incydentu Kwidzynie komenda włoska wysyła bersaglierów dla ochrony zebrań polskich, wskutek czego wiece od trzech tygodni mogą się odbywać spokojnie, tembardziej, że zwycięstwo mając zapewnione, Niemcy rzucili hasło nieprowokowania Polaków, zdając sobie sprawę, że w ten sposób kuliby broń przeciw sobie samym. 


\title{
BIBLIOGRAFIA:
}

\section{Źródła drukowane:}

Plebiscyty na Warmii, Mazurach i Powiślu w 1920 roku. Wybór źródeł, wyd. P. Stawecki, W. Wrzesiński, Olsztyn 1986.

\author{
Akty prawne: \\ 1929 Traktat pokoju między mocarstwami sprzymierzonemi i skojarzonemi i Niemcami, podpisanego w Wersalu \\ dnia 28 czerwca 1919 roku, cz. II, Dział IX Prusy Wschodnie, w: art. 94-98, s. 70-74, w: Dz. U. 1920 nr 35 \\ poz. 200 .
}

Relacje i wspomnienia:

Żeromski Stefan, Inter Arma, Warszawa-Kraków 1920.

Prasa:

„Gazeta Olsztyńska”

- $\quad$ 1920, nr 64, $29 \mathrm{~V}$.

„Gazeta Polska dla Powiatów Nadwiślańskich”

- $\quad$ 1920, nr 45, 22 V; nr 55, 5 VI; nr 66, 18 VI.

„Gazeta Warszawska”

- $\quad$ 1920, nr 153, 7 VI; nr 154, 8 VI; nr 167, 21 VI; nr 169, 23 VI.

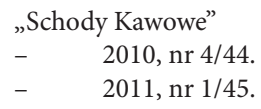

„Wiarus”

- $\quad 1920$, nr 26, 28 VI.

\section{Opracowania:}

Barganowski Antoni, Plebiscyt na Powiślu, Elbląg 1989.

- $\quad$ Plebiscyt na Ziemi Kwidzyńskiej, w: Plebiscyt na Powiślu - 11 lipiec 1920 rok, „Zeszyty Kwidzyńskie”, nr 1, Kwidzyn 2000.

Kempa Robert, Mazurskie reminiscencje rocznicowe. Powiat giżycki w 90. rocznicę plebiscytu, w: Białostockie Teki Historyczne, t. 8, Białystok 2010.

Kłodziński A.Z., Żeromski i Kasprowicz w czasie plebiscytu na Warmii i Mazurach w 1920 roku, „Teka Pomorska”, Toruń 1938.

Lietz Zygmunt, Plebiscyt na Powiślu, Warmii i Mazurach w 1920 roku, Warszawa 1958.

Liga Narodowa (1893-1928). Wybór relacji, opr. T. Sikorski, A.Wątor, Warszawa 2015.

Malinowski Jerzy, Stefan Dąbrowski (1877-1947). Biografia polityczna, Poznań 2014.

- Działalność Stefana Dąbrowskiego w związku z plebiscytami na Powiślu, Warmii i Mazurach w 1920 roku, „Komunikaty Mazursko-Warmińskie” 2011, nr 4 (274).

Wasilewski Zygmunt, Wspomnienia o Janie Kasprowiczu i Stefanie Żeromskim, Warszawa-Kraków-Lublin-ŁódźParyż-Poznań-Wilno-Zakopane 1927.

Wrzesiński Wojciech, Prusy Wschodnie w polskiej myśli politycznej 1864-1945, Olsztyn 1994.

- Polska - Prusy Wschodnie. Plebiscyty na Warmii i Mazurach oraz na Powiślu w 1920 roku, Olsztyn 2010.

Żerebny Michał, Kasprowicz w 1920 roku na Powiślu i Warmii, w: Jan Kasprowicz w siedemdziesięciolecie śmierci, Materiały Międzynarodowej Sesji Naukowej Olsztyn 17-19.X.1996, red. J. Kaczyński, Olsztyn 1999.

\section{Strony internetowe:}

- $\quad$ http://isap.sejm.gov.pl/isap.nsf/DocDetails.xsp?id=WDU19200350200 (dostęp: 2 XI 2020 r.).

- $\quad$ https://repozytorium.amu.edu.pl/bitstream/10593/2650/1/Dzia\%C5\%82alno\%C5\%9B\%C4\%87\%20polityczno-spo\%C5\%82eczna\%20prof.\%20Stefana\%20D\%C4\%85browskiego.pdf (dostęp: 2 XI 2020 r.). 